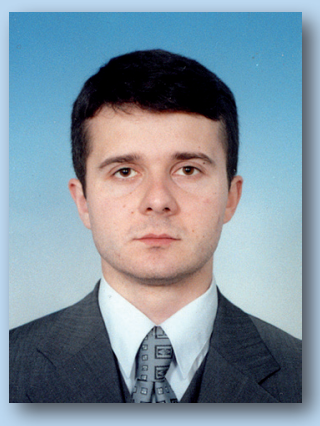

dr Dragan Jović

Centralna banka Bosne i Hercegovine djovic@bl.cbbh.ba

\title{
Rezime
}

Za predmet istraživanja smo izabrali loše kredite u bankarskom sektoru Bosne i Hercegovine. Cilj nam je bio da stvorimo modele za predviđanje njihovog kretanja. Pored raznovrsnih prostih linearnih regresionih modela $\mathrm{i}$ analize vremenske serije, koristili smo i alate tehničke analize, što je jedna velika novost u ovoj oblasti. Na loše kredite utiču: dospjela potraživanja, stopa rasta $B D P$ i kamatni raspon. Najvažniji rezultat istraživanja je verifikacija hipoteze da se alati tehničke analize mogu koristiti za predviđanje kretanja loših kredita. Dokazali smo i da različite metodologije za predviđanje i različiti regresioni modeli, sa različitim nezavisnim varijablama, odgovaraju različitim periodima razvoja loših kredita.

Ključne riječi: loši krediti, tehnička analiza, dospjela potraživanja, bruto društveni proizvod, kamatni raspon, Bosna i Hercegovina

JEL: G21, E59 


\section{NPLs MODELING IN THE BANKING SECTOR OF BOSNIA AND HERZEGOVINA}

dr Dragan Jović

Central Bank of Bosnia and Herzegovina djovic@bl.cbbh.ba

\section{Summary}

We have chosen non-performing loans in Bosnia and Herzegovina's banking sector for the subject of this research. Our goal was to create models for forecasting of their movements. In addition to different simple linear regression models and time series analysis, we have also used the tools of technical analysis, which is major innovation in this area. Variables affecting non-performing loans are: matured receivables, GDP growth rate, and interest rate spread. The most important result of this research is the verification of our hypothesis that the tools of technical analysis can be used for forecasting the trends of non-performing loans. We have proved that different methodologies for prediction and different regression models, with different independent variables, suit different periods of NPLs development.

Keywords: non-performing loans, technical analysis, overdue, gross domestic product, interest rate spread

JEL: G21, E59 


\section{Uvod}

Ekonomska kriza se ispoljava na više načina. U bankarskom sektoru najočigledniji je pad kvaliteta bankarskih aktiva. Na području druge Jugoslavije, pa i Bosne i Hercegovine, one se u najvećem djelu sastoje od kredita. Finansijski instrumenti su zastupljeni $u$ vrlo niskom procentu, pa su zato glavni pojavni oblik kvarenja bankarskih aktiva loši krediti (u daljem tekstu $L K)$. Kao takvi, oni nisu direktno vidljivi u bilansu. Do njih se dolazi kroz proces klasifikacije kredita. Prema najgrubljoj podijeli, u LK bi trebali spadati krediti po kojima dužnik kasni sa plaćanjem duže od 90 dana. Dužnička docnja je glavni kriterij za klasifikaciju. U LK spadaju krediti iz C (dužnička docnja iznad 90 dana), $D$ (iznad 180 dana) i $E$ (iznad 270 dana) kategorije. Krediti u $B$ kategoriji spadaju u klasifikovanu aktivu, ali ne i u lošu aktivu, a krediti svrstani u $A$ kategoriju su prvoklasna aktiva. U stručnoj literaturi $L K$ se označavaju i kao neperformansni krediti (nonperforming loan, bad loans).

Predmet istraživanja su $L K \mathrm{u}$ bankarskom sektoru BiH (u daljem tekstu BSBiH). LK dovodimo u vezu sa dospjelim potraživanjima (u daljem tekstu $D P$ ), kamatnim rasponom (u daljem tekstu $K R$ ) i stopom rasta nominalnog bruto društvenog proizvoda (BDP s.r). Cilj nam je da razvijemo modele za predviđanje $L K$, direktno na osnovu podataka o $L K$, putem tehničke analize $\mathrm{i}$ analize vremenske serije, i indirektno preko $D P, K R$ i BDP s.r. $\mathrm{U}$ istraživanje ulazimo sa hipotezom da je za predviđanje kretanja $L K$ potrebno kombinovati različite metodologije i modele, da različitim periodima razvoja $L K$ odgovaraju različiti modeli, kao i da se čak i tehnička analiza može uspješno primjeniti na analizu i predviđanje $L K$.

U prvom dijelu istraživanja prezentujemo metodološku osnovu rada, a zatim dajemo kratak literarni pregled. U trećem dijelu predstavljamo rezultate istraživanja; osnovne karakteristike serije $L K$, primjena tehničke analize $\mathrm{u}$ predviđanju $L K$, uspostavljanje veze između $D P$ i $L K$ i analiza prediktivnih sposobosti $D P$, razvijanje regresionih modela $L K$ vs. $B D P$ s.r. i $L K$ vs. $K R$, i analiza vremenske serije $L K$ upotrebom polinoma drugog reda. $U$ zaključku pored sumiranja rezultata istraživanja ukazujemo na određene dileme i potencijalne pravce novih istraživanja.

\section{Materijal i metode}

Informacionu osnovu rada čini finansijska statistika koju publikuje Centralna banka Bosne i Hercegovine i neto bilansi bankarskog sektora Republike Srpske (Agencija za bankarstvo Republike Srpske) i bankarskog sektora Federacije Bosne i Hercegovine (Agencija za bankarstvo Federacije BiH).

Glavni metodološki alati istraživanja su prosta linearna regresiona analiza, tehnička analiza, deskriptivna statistika i analiza vremenske serije. Za ocjenu regresionih modela koristimo standardnu metodologiju [Žižić et al, 1992: 273-317], a isto tako i za analizu vremenskih serija [Žižić et al, 1992: 397-449]. U modeliranju LK preko vremenske serije upotrebljen je polinom drugog reda.

$L K$ i DP nisu predstavljani kao apsolutne, već kao relativne, procentualne vrijednosti; $L K \mathrm{u}$ odnosu na ukupne kredite, a $D P \mathrm{u}$ odnosu na ukupna potraživanja po kreditima, lizingu i kamati. Analiza obuhvata period od 13 godina - od kraja 2000. g. do Q2 2012. g. Podaci za $L K$ i $R O E$ za sve godine su kvartalni, osim za 2000. g. i 2001. g. za koje su godišnji. Vremenska serija $D P$ je na godišnjem nivou (2000 - 2011), kao i vremenska serija BDP s.r., ali za kraći vremenski period (2003 - 2011). KR (u procentnim poenima/p.p.) računamo kao razliku između aktivnih i pasivnih kamatnih stopa. Aktivne kamatne stope su kamatne stope na kratkoročne KM kredite privredi, a pasivne kamatne stope su kamatne stope na oročene i štedne depozite privrede u KM. Vremenska serija $K R$ započinje u 09/2004, a završava u 06/2012. g.

Monetarno-bankarska statistika prati $L K$ na kvartalnom nivou. Banke raspolažu sa mjesečnim podacima o $L K$, a zavisno od njihovog informacionog sistema, i sa učestalijim podacima od mjesečnih. Serija $L K$ je vremenska serija, kao što je i vremenska serija cijena finansijske aktive - npr. tržišna cijena akcija. Tehnička analiza je metoda analize i predviđanja kretanja cijena akcija. Polazi od pretpostavke da se na bazi prethodnih cijena akcije i protrgovanih volumena mogu odrediti 


\section{Introduction}

An economic crisis can be reflected in several ways. In the banking sector the most obvious is the decline in the quality of banking assets. On the territory of the second Yugoslavia, including Bosnia and Herzegovina, they mostly consist of loans. Financial instruments are present in a rather low percentage, hence the main form corrupting banking assets are non-performing loans (hereafter referred to as NPLs). As such, they are not directly visible in the balance sheet. They are reached through the process of loans classification. According to the roughest division, NPLS should include loans in respect of which the debtor defaulted for over 90 days. Debtors' default is the main criterion for classification. NPLs include loans from the categories $C$ (debtors' default over 90 days), $D$ (over 180 days) and $E$ (over 270 days). Loans in the category $B$ qualify as classified assets, but not bad assets, whereas loans in the category $A$ are first-class assets. In technical literature NPLs are referred to as non-performing loans or bad loans.

The subject of our research is NPLs in the banking sector of Bosnia and Herzegovina (hereafter referred to as $B S B \mathcal{E} H$ ). We bring NPLS in relation to matured receivables (hereafter referred to as $M R$ ), interest rate spread (hereafter referred to as IRS) and the growth rate of gross domestic product (GDP g.r). The goal is to develop models for NPLs forecasting, directly based on available data on NPLs, by means of technical analysis and time series analysis, and indirectly by means of MR, IRS, and GDP g.r. We start the research with the hypothesis that the forecasting of NPLs movements requires a combination of different methodologies and models; that the different periods of NPLs development require different models, and that even the technical analysis can be successfully implemented in the process of analyzing and forecasting NPLs.

The first part of the research presents the methodological basis of the paper, which is followed by a brief review of bibliographical references. The third segment features the research results, i.e. the main characteristics of the NPLs series, the implementation of technical analysis in the process of NPLs forecasting, establishing the connection between $M R$ and NPLS and analyzing the predictive capabilities of $M R$, developing regression models NPLS vs. GDP g.r. and NPLs vs. IRS, as well as the time series analysis of NPLs by means of a secondorder polynomial. In addition to summing up the research results, the conclusion highlights certain dilemmas and potential directions for further research.

\section{Material and methods}

The information basis of this paper is financial statistics published by the central bank of Bosnia and Herzegovina, and the net balance sheets of the banking sector of the Republic of Srpska (Banking Agency of the Republic of Srpska) and the banking sector of the Federation of Bosnia and Herzegovina (Banking Agency of the Federation of $B \& H)$.

The main methodological research tools are simple linear regression analysis, technical analysis, descriptive statistics and time series analysis. To assess regression models, we use standard methodology [Žižić et al, 1992: 273317], and the same goes for time series analysis [Žižić et al, 1992: 397-449]. In modeling NPLs through a time series, we used a second-order polynomial.

NPLs and MR were not presented as absolute, but relative percentage values; NPLS in relation to total loans, and $M R$ in relation to total receivables in respect of loans, leasing and interest. The analysis encompasses a period of 13 years - from the end of 2000 to Q2 2012. The data on NPLs and ROE for all years are quarterly, except for 2000 and 2001 when they are annual. The time series of $M R$ is at the annual level (2000-2011), just like the time series of GDP g.r., but for a shorter period of time (2003-2011). IRS (in percentage points/p.p.) is calculated as a difference between active and passive interest rates. Active interest rates are interest rate on short term corporate loans in convertible marks $(\mathrm{KM})$, whereas passive interest rates are interest rates on corporate time and savings deposits in convertible marks (KM). The IRS time series starts in 09/2004, and ends in 06/2012.

The monetary and banking statistics follows NPLS at the quarterly level. Banks hold the monthly data on NPLs, and depending on their 
buduće cijene akcije, odnosno trend kretanja cijene. Tehnička analiza se može primjeniti i na seriju $L K$, uz poštovanje razlika. Prva razlika je u tome što je $L K$ procenat (relativna vrijednost), a cijena akcije apsolutna vrijednost. Druga razlika između ovih serija je što kod analize cijena finansijske aktive pored cijene raspolažemo i sa obimom trgovine. Treća razlika je u frekvenciji podataka: cijena finansijske aktive je, ili dnevna, ili unutar dnevna, dok podaci o $L K$ uopšte nisu gusti - oni su zvanično kvartalni. Podatak o $L K$ je jedinstven za razliku od cijene akcija koja se grana u četiri cijene: cijenu otvaranja, cijenu zatvaranja, najvišu i najnižu cijenu. To je četvrta razlika.

Zbog ovih razlika odabrali smo tri vrlo jednostavna i praktična alata tehničke analize: nivo podrške (support level), linija trenda (trend line), impuls (momentum, MOM) i stopa promjene (rate of change, ROC).

Nivo podrške (support level) i nivo otpora (resistence level) je razvio i primjenjivao Dow Jones. Na tržištu akcija nivo podrške je nivo cijena akcija pri kojoj tržište ne dozvoljava dalji pad cijena akcija. Na nivou podrške kupovni nalozi nadmašuju prodajne naloge, što dovodi do zaustavljanja pada cjene. Pošto pad $L K$ predstavlja pozitivnu pojavu, a termin nivo podrške je preuzet sa finansijskog tržišta gdje pad cijene aktive predstavlja negativnu pojavu, logičniji i prikladniji naziv za nivo na kojem se formira otpor daljem padu $L K$ bi bio nivo otpora, a ne nivo podrške.

Linija trenda (trend line) je vrlo jednostavan, ali i koristan, alat tehničke analize. Linija trenda spaja, ili sukcesivne rastuće dolje trenda (higher lows), ili seriju opadajućih vrhova (lower highs). Presjek ovako konstruisane linije trenda i cijene akcija, a u našem istraživanju vremenske serije $L K$, je znak da se - sa velikim stepenom izvjesnosti - može očekivati promjena trenda.

Koncept impulsa/momentuma (MOM) potiče iz fizike. Predstavlja stopu po kojoj brzina nekog objekta raste ili opada. Na tržištu akcija indikator impulsa mjeri da li se kretanje cjena akcija ubrzava ili usporava, a mi smo ga upotrjebili za mjerenje promjene $L K$. Impuls predstavlja razliku između prve i zadnje vrijednosti vremenske serije $u$ određenom vremenskom horizontu. U istaživanju smo koristili ROC 3 (razlika između LK u prvom i trećem kvartalu), ROC 6 (razlika između $L K$ u prvom i šestom kvartalu) i ROC 10 (razlika između $L K$ u prvom i desetom kvartalu).

Stopa promjene cjene (the price rate of change - ROC) mjeri intenzitet promjene cijene tokom vremena. Indikator je nastao na konceptu impulsa, s tom razlikom da utvrđuje relativnu/ procentualnu, a ne apsolutnu promjenu. ROC daje informaciju o relativnoj razlici između tekuće i neke prethodne vrijednosti $L K$. ROC raste kada $L K$ raste, a opada kada $L K$ pada. Upotrjebili smo ROC 3, ROC 6 i ROC 10. Što je $R O C$ manji, raste vjerovatnoća rasta $L K$ i obratno.

\section{Literarni pregled}

Istraživanja na temu uticaja bankarskih i makroekonomskih varijabli na loše kredite u bankarskom sektoru su obimna i vrlo raznovrsna. U nama geografski bliskoj zemlji (Rumunija) istraživana je korelacija između prosječnih kamatnih stopa i loših kredita [Socol, Adela i Iuga, Julia, 2010: 777]. Korelacija je utvrđena (mjerena Pearsonovim koeficjentom korelacije), ali i postojanje "drugih indirektnih kanala koji utiču na loše zajmove". Glavni nalaz istraživanja uzroka rasta loših zajmova u Tanzaniji [Evelyn, 2011: 50] je da je uzrok rasta loših zajmova nenamjensko korištenje kredita, kao i da rigorozan monitoring upotrebe kredita ograničava rast loših kredita. Ovo istraživanje je sprovedeno ispitivanjem 48 visokih bankarskih službenika. Bankarski sektor Tunisa [Bahrini, 2011: 230] pokazuje da su loši zajmovi vezani za kvalitet menadžmenta i moralni hazard. Modeli za predviđanje loših zajmova uključuje i bankarske i makroekonomske varijable [Greenidge, Kevin i Grosvener, Tiffany, 2010: 79]. Loše krediti po svim kategorijama u bankarskom sektoru Grčke objašnjavaju uglavnom makroekonomske varijable - BDP, nezaposlenost, kamatne stope, javni dug - i kvalitet menadžmenta [Louzis et al., 2012: 79]. Na izmjenu makro-varijabli najslabije reaguju hipotekarni krediti. Volatilnost kamatnih stopa utiče, ali ne apsolutno, na loše kredite, poruka je istraživanja u pakistanskom bankarskom sektoru za period 1996Q4 - 2011Q3 [Siddiqui, 2012: 66]. 
IT systems, also the data on a more frequent basis. The NPLs series is a time series, just like the time series of financial assets prices - for instance, stock market prices. Technical analysis is a model used to analyze and predict the stock prices movements. It starts from the assumption that the previous stock prices and traded volumes can be used as a basis to determine the future stock prices, i.e. the trends in price movements. Technical analysis can also be applied to the NPLs series, the relevant differences being taken into account. The first difference is that NPLs are in percentages (i.e. a relative value), whereas the stock prices are an absolute value. The second difference between these series is that in the process of analyzing the prices of financial assets, in addition to the price, we also have trade volumes to take into account. The third difference refers to the frequency of data: financial assets price is either daily or inter-daily, whereas the NPLs data are not frequent at all - they are officially given at a quarterly level. Every piece of data on NPLS is unique, as opposed to the stock price which is broken down into four prices: opening price, closing price, highest price and lowest price. That is the fourth difference.

Due to these differences, we have chosen three rather simple and practical tools of technical analysis: support level, trend line, momentum, MOM, and rate of change, ROC.

Support level and resistance level were developed and applied by Dow Jones. At the stock market the support level is the level of stock prices at which the market does not allow the stock prices to decline any further. At the support level, the bidding orders surpass the selling orders, which causes the prices to stop declining. Given that a drop in NPLs is a positive phenomenon, and the term "support level" has been taken from the financial market where a drop in stock prices is a negative thing, "resistance level" would be a more logical and appropriate name for the level at which resistance to a further decline in NPLs forms.

Trend line is a very simple, but useful tool of technical analysis. The trend line connects either the higher lows or the lower highs. The cross-section of a thereby constructed trend line and the stock price, i.e. in our research the NPLs time series, indicates that - with a high degree of certainty - one can expect a trend change.

The concept of momentum (MOM) comes from physics. It refers to the rate at which the speed of an entity increases or decreases. At the stock market the momentum indicator measures whether the stock prices movements are accelerating or decelerating, and in our research we used it to measure the changes in NPLS. Momentum represents the difference between the first and the last value of the time series over a specific time horizon. In our research we used ROC 3 (the difference between NPLS in the first and the third quarter), ROC 6 (the difference between NPLs in the first and the sixth quarter) and ROC 10 (the difference between NPLs in the first and the tenth quarter).

The price rate of change - ROC measures the intensity of price changes over time. This indicator is based on the concept of momentum, the difference being that it determines the relative/percentage change instead of the absolute one. ROC provides the information about the relative difference between the current and some previous value of NPLS. ROC grows when NPLs grow, and it drops when NPLs drop. We used ROC 3, ROC 6 and ROC 10. The lower the ROC, the higher the probability of NPLs growth, and vice versa.

\section{References review}

Studies on the topic of how banking and macroeconomic variables affect non-performing loans in the banking sector are numerous and rather diverse. In a geographically close country (i.e. Romania) there have been studies on the correlation between average interest rates and non-performing loans [Socol, Adela and Iuga, Julia, 2010: 777]. The correlation has been confirmed (measured by the Pearson correlation coefficient), along with the existence of "other indirect channels affecting non-performing loans". The main findings in the research of what causes the NPLs growth in Tanzania [Evelyn, 2011: 50] are that the non-performing loans grow because of the non-purposeful utilization of the loans, and that a rigorous monitoring of loans utilization limits the growth of NPLS. This research was conducted by examining 48 top banking officials. The banking sector of Tunisia [Bahrini, 2011: 230] suggests that non- 


\section{Rezultati istraživanja}

\section{Distribucija frekvencije i deskriptivna statistika}

Vremenska serija sa početkom u Q4 2000 i krajem u Q3 2012 ima 41 kvartal (Tabela 1). U prosjeku (aritmetička sredina) BSBiH funkcioniše na nivou $L K$ od 7,59 \%. Vrijednost $L K$ od 6,1 dijeli seriju na dva djela - to je medijana. U 3 slučaja $L K$ je 5,3 \% i 3 \% (modusi). Najviši $L K$ je 21,2 \% (Q4 2000), a najniži 3 \% (prvi put se pojavljuje 31.12.2007. g.). Raspon (razlika između maksimalne i minimalne vrijednosti $L K$ ) od 18,2 p. p. (procentnih poena) tumačimo kao veliki varijabilitet $\mathrm{u}$ kretanju $L K$.

Tabela 1. Distribucija frekvencije $L K, B S B i H(Q 4$ 2000 - Q3 2012) (Model 1)

\begin{tabular}{cccc}
\hline Interval & Broj & Struktura & Kumulativno \\
\hline $0-3$ & 3 & $7,3 \%$ & $7,3 \%$ \\
$3,1-6$ & 17 & $41,5 \%$ & $48,8 \%$ \\
$6,1-9$ & 7 & $17,1 \%$ & $65,9 \%$ \\
$9,1-12$ & 9 & $22,0 \%$ & $87,8 \%$ \\
12,1 i 15 & 3 & $7,3 \%$ & $95,1 \%$ \\
15,1 & 2 & $4,9 \%$ & $100,0 \%$ \\
\hline & 41 & $100,0 \%$ &
\end{tabular}

Izvor: http://www.cbbh.ba (pristupljeno 10.10.2012. g.) (obradio autor).

Grafikon 1. Histogram frekvencije, $L K$

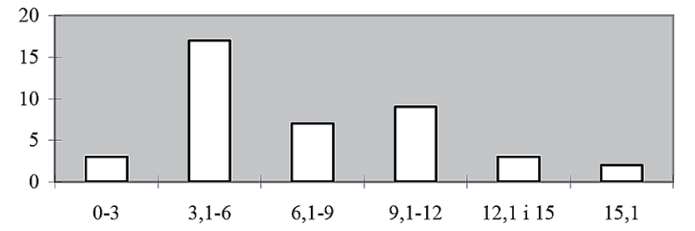

Izvor: Ibid.

Nalaze o visokom varijabilitetu potvrđuje koeficijent varijacije (standardna devijacija/ aritmetička sredina) od 0,56 . U prosjeku $L K$ odstupaju od aritmetičke sredine serije $L K$ za + - 56\%. Raspored $L K$ je asimetričan u desnu stranu (grafikon 1), treći momenat je 1,16, a kod normalnog rasporeda on je 0 . Dugi rep (long tail), ekstremne vrijednosti $L K$, se nalaze $\mathrm{u}$ desnom dijelu rasporeda. Raspored $L K$ je spljošten. Njegov četvrti momenat je 1,38 (za normalni raspored je 3). I po spljoštenosti i simetričnosti raspored $L K$ značajno odstupa od normalnog rasporeda.
Vjerovatnoća da će $L K$ na nivou $B S B i H$, ili pojedinačne banke, biti 3\%, ili ispod 3\%, je 7,3\%. Najviše vrijednosti $L K, 41,5 \%$, spada u interval od 3,1 do 6. 65,8\% vrijednosti $L K$ je manje, ili jednaka 9\%. 22,5\% vrijednosti $L K$ pada u interval od 9,1\% do $12 \%$. Ovaj interval označava prelaz ka izuzetno visokim vrijednostima $L K$.

\section{Tehnička analiza}

Linije trenda (grafikon 2, Model 2), dobijene spajanjem najviših tačaka u opadajućem trendu (lower highs) presjeca seriju $L K \mathrm{u}$ dvije tačke; na dan 31.12.2007. g. kada je $L K 3 \%$, i na dan 30.09.2008. g., kada je $L K 3,3 \%$. Preokret u trendu se metodom linije trenda identifikuje već krajem 2007. g. Signal je potvrđen u Q1 2008. g., a prema empirijskim podacima očigledan je tek u Q3 2009. g., kada se $L K$ sa početnih 3\% penju na $4,8 \%$. Dakle, metoda linije trenda je predvidjela rast $L K 2$ godine i 9 mjeseci prije nego što je to postalo očigledno. Do istog zaključka, mada ne tako egzaktnog, kao što je to slučaj sa linijom trenda, dolazimo analizom nivoa podrške (grafikon 3, Model 3). On se formira na nivou $L K$ od oko $3 \%$. U toj vrijednosti trend opadanja $L K$ je zaustavljen. Formirani nivo podrške/ otpora 8 kvartala uzastopno (Q2 2007 - Q1 2009) ne dozvoljava da $L K$ padnu ispod $3 \%$. Nakon dvije godine (30.06.2007 - 31.03.2009) otpor padu $L K$ se konačno pretvara $\mathrm{u}$ rast LK iznad nivoa od 3\%. Nivo podrške/otpora pokazuje da se već polovinom ili krajem 2007. g. mogao predvidjeti, i očekivati, rast $L K$ iznad $3 \%$. A do rasta $L K$ značajno iznad 3\% dolazi tek polovinom 2009. g.

Grafikon 2. Linija trenda, $L K$, Model 2

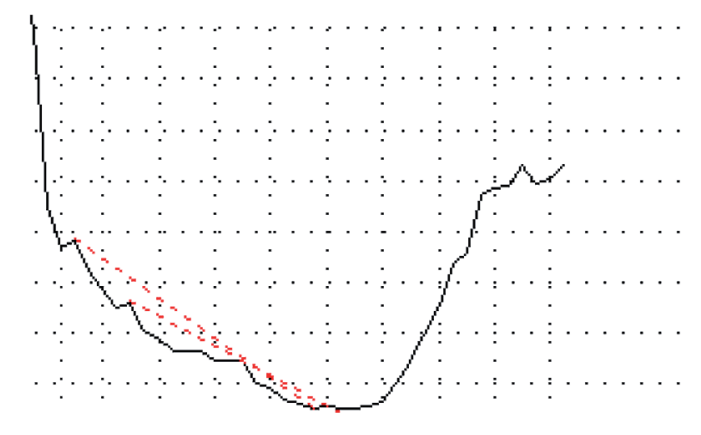

Izvor: Ibid. 
performing loans are related to the quality of management and moral hazard. The models for NPLS forecasting include both banking and macroeconomic variables [Greenidge, Kevin and Grosvener, Tiffany, 2010: 79]. Non-performing loans in all categories in the banking sector of Greece are mostly explained by macroeconomic variables - GDP, unemployment, interest rates, public debt - and management quality [Louzis et al., 2012: 79]. Mortgage loans are the ones responding the least to the changes in macro variables. Volatility of interest rates impacts non-performing loans, but not in absolute terms, as was the conclusion of the research in the Pakistani banking sector for the period 1996Q42011Q3 [Siddiqui, 2012: 66].

\section{Research results}

\section{Frequency Distribution and Descriptive Statistics}

The time series commencing in Q4 2000 and ending in Q3 2012 encompasses 41 quarters (Table 1). On average (arithmetic mean) BSBEH functions at the NPLS level of $7.59 \%$. The NPLS value of 6.1 divides the series in two sections - that is the median. In 3 cases the NPLs level is $5.3 \%$ and $3 \%$ (modes). The highest NPLS level is $21.2 \%$ (Q4 2000), and the lowest 3\% (first appearing on 31.12.2007). The spread (i.e. the difference between the maximum and minimum NPLs value) of 18.2 p.p. (percentage points) is interpreted as high variability in the NPLS trends.

Table 1. NPLs frequency distribution, BSBEH (Q4 2000 - Q3 2012) (Model 1)

\begin{tabular}{|c|c|c|c|}
\hline Interval & Number & Structure & Cumulative \\
\hline $0-3$ & 3 & $7,3 \%$ & $7,3 \%$ \\
\hline $3,1-6$ & 17 & $41,5 \%$ & $48,8 \%$ \\
\hline $6,1-9$ & 7 & $17,1 \%$ & $65,9 \%$ \\
\hline $9,1-12$ & 9 & $22,0 \%$ & $87,8 \%$ \\
\hline 12,1 i 15 & 3 & $7,3 \%$ & $95,1 \%$ \\
\hline \multirow[t]{2}{*}{15,1} & 2 & $4,9 \%$ & $100,0 \%$ \\
\hline & 41 & $100,0 \%$ & \\
\hline $\begin{array}{l}\text { Source: http:// } \\
\text { by the author) }\end{array}$ & vw.cbbh & (accessed & .2012) (prepared \\
\hline
\end{tabular}

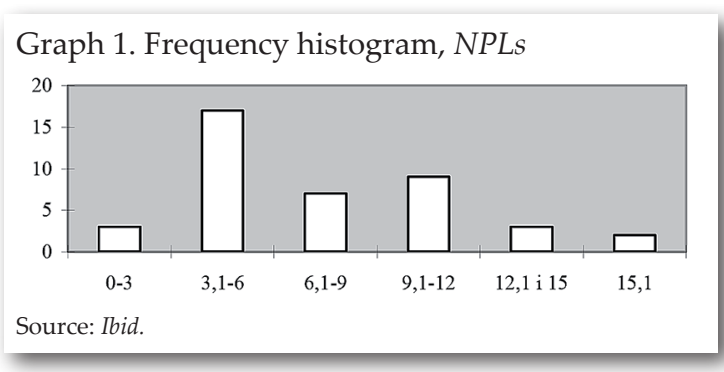

The findings about high variability are confirmed by the variation coefficient (standard deviation/arithmetic mean) of 0.56 . On average, NPLS deviate from the arithmetic mean of the NPLs series by $+/-56 \%$. NPLs distribution is skewed to the right (Graph 1), the third moment is 1.16, while in normal distribution it equals 0 . The long tail, i.e. the extreme values of NPLs, is located in the right segment of the distribution. The NPLS distribution is flat (platykurtic). Its fourth moment is 1.38 (in case of normal distribution it equals 3). In terms of both kurtosis and skewedness, NPLs distribution significantly deviates from normal distribution.

The probability that NPLs at the level of $B S B \mathcal{E} H$, or individual banks, will be $3 \%$ or below 3\% amounts to $7.3 \%$. The highest portion of NPLs, $41.5 \%$, falls into the interval from $3.1 \%$ to $6 \% .65 .8 \%$ of NPLs are less than or equal to $9 \% .22 .5 \%$ of NPLs fall into the interval from $9.1 \%$ to $12 \%$. This interval signifies the transition towards the extremely high values of NPLs.

\section{Technical Analysis}

The trend line (Graph 2, Model 2) obtained by connecting the lower highs intersects with the NPLS series at two points: on 31.12.2007 when NPLs were $3 \%$, and on 30.09 .2008 , when NPLS were $3.3 \%$. A shift in the trend is by means of the trend line method identified already in late 2007. The signal is confirmed in Q1 2008, and according to the empirical data it was not evident until Q3 2009, when the NPLs from the initial 3\% grew to $4.8 \%$. Therefore, the trend line method anticipated the growth of NPLs 2 years and 9 months before the change became obvious. The same conclusion, though not that exact as in the case of trend line, is reached by analyzing support levels (Graph 3, Model 3). It is formed at the NPLs level of about $3 \%$. It was at this value that the declining trend of NPLs was stopped. The formed support/resistance level in 8 consecutive quarters (Q2 2007-Q1 


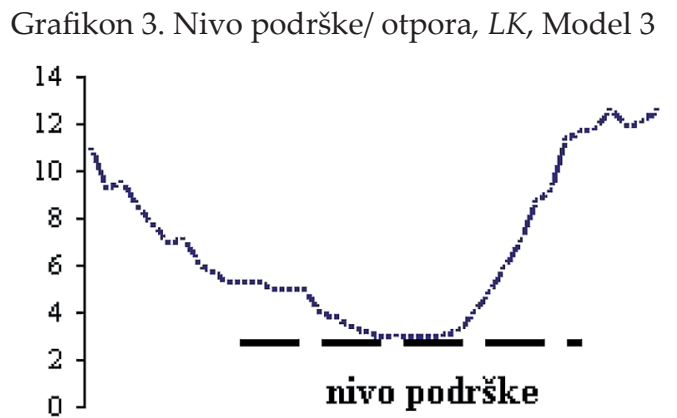

Izvor: Ibid.

\section{Grafikon 4. LK i ROC, BSBiH, Model 4}
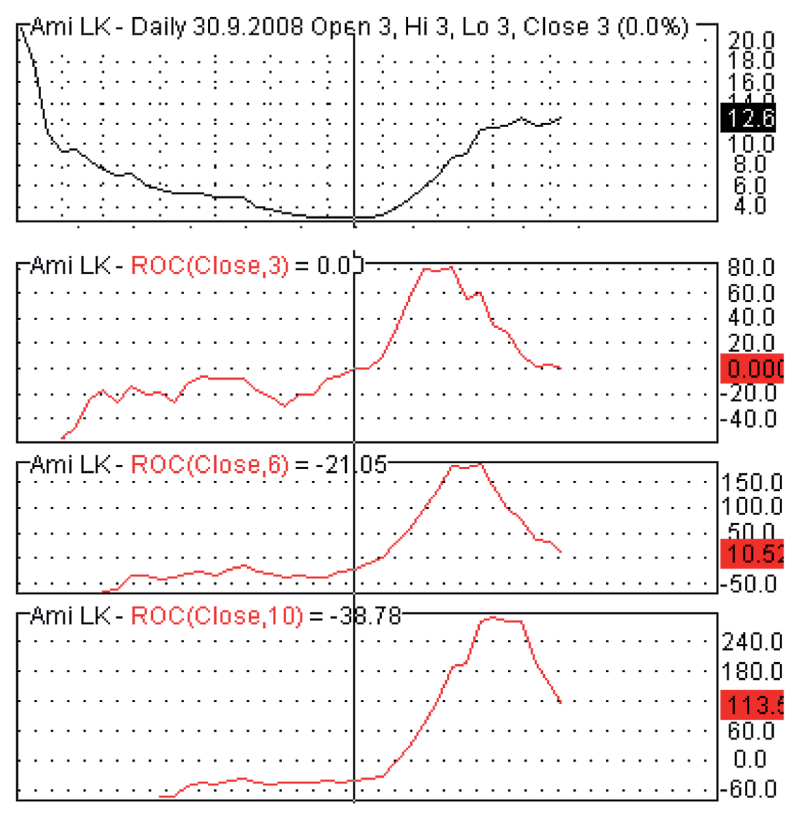

Izvor: Ibid.
ROC je određen za 10,6 i 3 dana. Za indiciju očekivane promjene trenda $L K$ smo uzeli $L K$ od $3 \%$ i njegovu stopu rasta ROC 3 od $0 \%$. To se prvi put desilo u Q3 2008, kada su ROC 6 i ROC 10 oko $-20(-21,05)$ i ispod - $40(-38,78)$. Zastoj u opadanju $L K$, koji signalizira budući rast $L K$, ROC 3 otkriva već u Q3 2008. g. Do potvrde ovih pretpostavki dolazi nakon godinu dana. $L K$ se značajno pomjera iznad 3\% tek u Q2 2009 (4\%) i Q3 2009 (4,8 \%). Opšti zaključak je da preokret u kretanju $L K$ nagovještava niska vrijednost $L K$ (u odnosu na prošle vrijednosti) unutar intervala otpora, koja pri tome ima ROC 3 koji teži ka nuli. Preokret nagovještava ROC 3 na nivou od oko nula, vrijednost ROC 6 od oko 20 i vrijednost ROC 10 ispod 40 (Model 4). Ovo su numerički parametri na osnovu kojih se može predvidjeti rast $L K$ (grafikon 4).

Do sličnih zaključaka dolazimo ako umjesto ROC upotrebimo impuls (MOM). Za razliku od $R O C, M O M$ mjeri ubrzanje/ usporenjekretanjakaorazliku u vrijednostima $L K$, a ne kao količnik vrijednosti $L K$. Za MOM 3 od nula, u trenutku kada je $L K 3 \%$ i unutar nivoa otpora/podrške, MOM 6 i MOM 10 su -0,8 i -1,9 (Grafikon 5, Model 5). Oni padaju ispod $1 \mathrm{tj}$. ispod 2. To su ključne vrijednosti $M O M$, kada je $L K$ unutar intervala otpora, koje najavljuju promjenu trenda $L K$, i to $\mathrm{u}$ ovome slučaju čak godinu dana ranije prije nego što do očigledne promjene trenda i dođe (30.09.2009. g.).

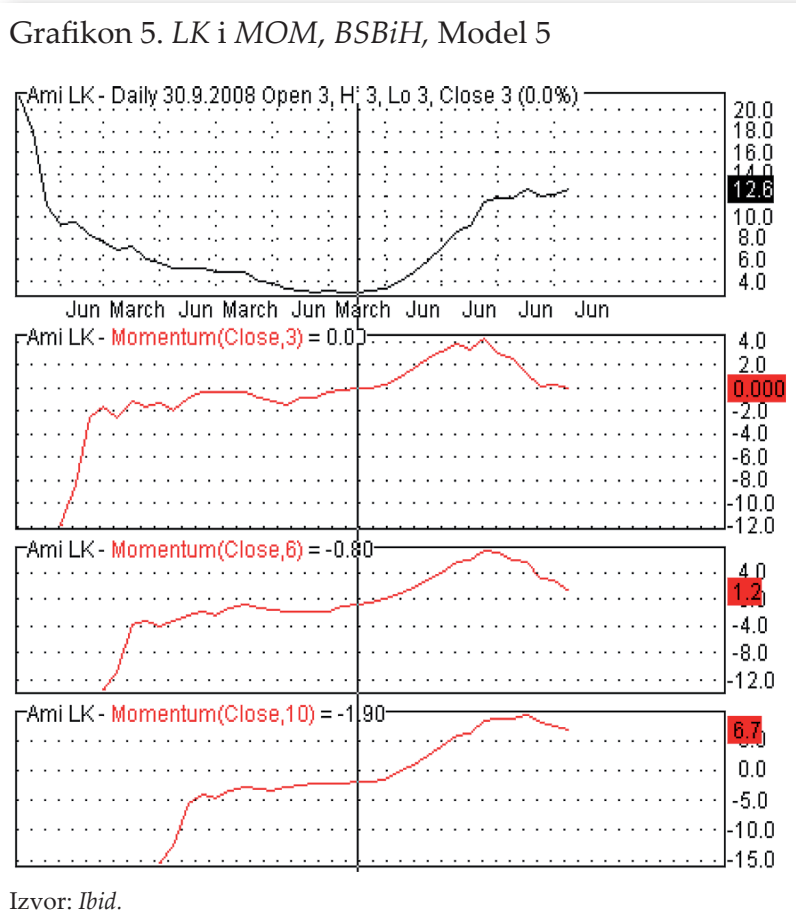


2009) does not allow the NPLs to drop below $3 \%$. After two years (30.06.2007-31.03.2009) the resistance to NPLS decline finally turns into a growth of NPLS above the level of 3\%. The support/resistance level indicates that already in mid or late 2007 one could have anticipated, and expected, the growth of NPLs above $3 \%$. It was not until the mid-2009, however, that the NPLS started to grow considerably above $3 \%$.

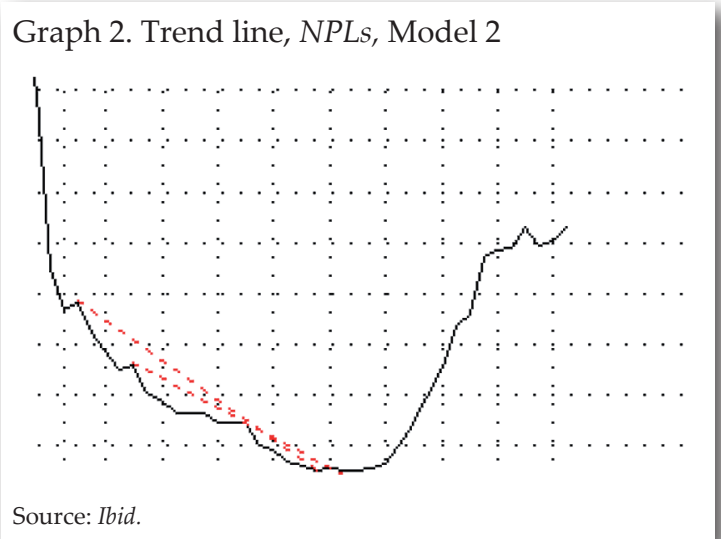

Graph 3. Level of support/resistance, NPLs, Model 3

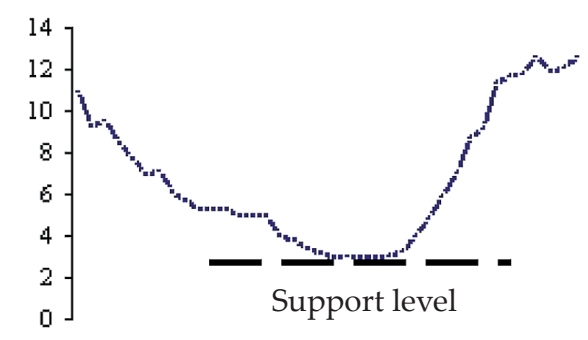

Source: Ibid.
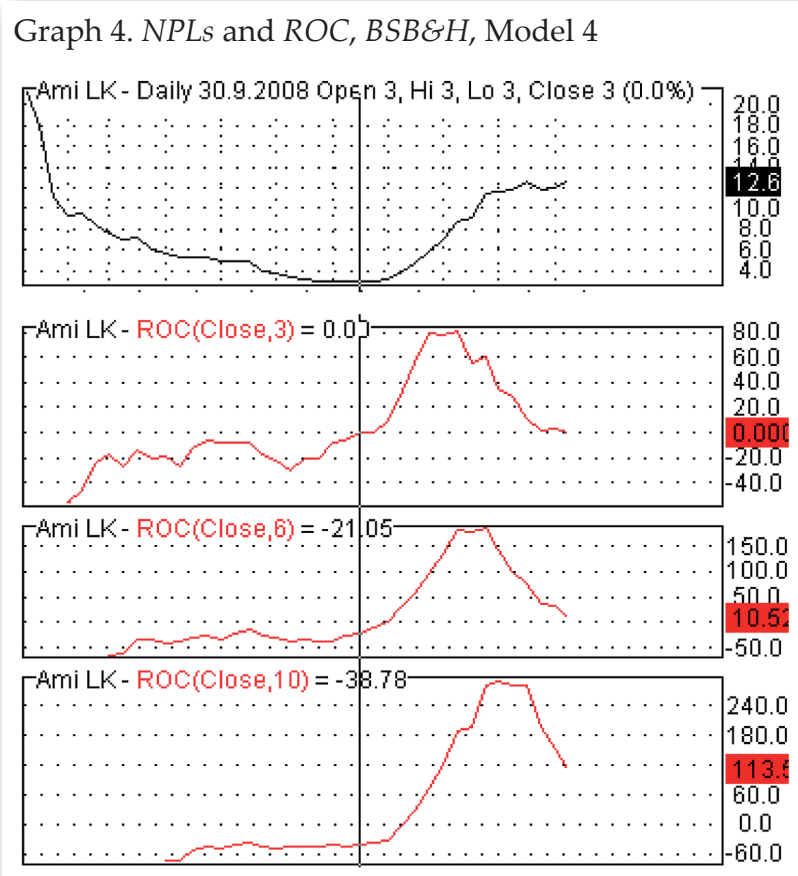

Source: Ibid.
$R O C$ is set at 10, 6 and 3 days. As indication of the expected change in the NPLs trend, we took the NPLs at $3 \%$ and their growth rate ROC 3 of $0 \%$. This first happened in Q3 2008, when ROC 6 and ROC 10 were about $-20(-21.05)$ and below -40 (-38.78). A standstill in the NPLs decline, signalizing the future growth of NPLS, was detected by ROC 3 already in Q3 2008 . These assumptions were confirmed after one year. NPLs substantially exceeded 3\% only in Q2 2009 (4\%) and Q3 2009 (4.8\%). The general conclusion is that a shift in the NPLs trend is suggested by the low value of NPLs (in relation to the past values) within the resistance interval, with $R O C 3$ approaching zero. The shift is anticipated by ROC 3 at the level approaching zero, the value of ROC 6 of about 20 and the value of ROC 10 below 40 (Model 4). These are the numerical parameters based on which one can anticipate the growth of NPLs (Graph 4).

Similar conclusions are reached if, instead of $R O C$, we use momentum (MOM). Unlike ROC, $M O M$ measures acceleration/deceleration of trends as a difference in the values of NPLS, and not as the quotient of NPLs values. For MOM 3 equaling zero, in the moment when NPLs are $3 \%$ and within the support/resistance level, MOM 6 and MOM 10 are -0.8 and -1.9 (Graph 5 , Model 5). They are below 1 i.e. below 2 . These are the key values of MOM, when NPLs remain within the resistance interval, announcing a change in the NPLs trend, in this case already one year before the evident change in the trend actually occurred (30.09.2009). 


\section{Dospjela potraživanja}

Prema jednoj, vrlo gruboj podjeli, potraživanja po kreditima se dijele na: potraživanja po glavnici kredita, potraživanja po poslovima lizinga i dospjela potraživanja. $U$ 2000. g. DP je 13,74\% (Grafikon 6). Od 2004. g. snaga opadajućeg trenda $D P$ slabi.

Nakon rapidnog smanjenja, u 2002. g. za 5,3 p.p. u odnosu na 2001. g., u 2004. g. DP su smanjeni za svega 0,6 p.p. Sličan zastoj u padu $D P$ je vidljiv i u tri naredne godine (do 2007. g.), a u 2008. g. godišnji prirast tj. pad $D P$ je svega - 0,1 p.p. Nakon dostizanja granica pada $D P$ prvi put nakon 9 godina počinju rasti. Godišnji prirast DP u 2009. g., 2010., i 2011., je 1,5 p.p., 2,1 p.p. i 3,5 p.p. respektivno. Prema godišnjem priraštaju/padu $D P$, rast $D P$ do kojeg dolazi prvi put u 2009. g. mogao se predvidjeti/ naslutiti već na osnovu usporenja pada $D P$ u 2004. g. (Model 6). Granica rasta je poznat koncept $u$ društvenim i ostalim naukama. Sve se razvija, raste/pada i dostiže svoj maksimum, ili minimum, nakon čega dolazi do pada, ili rasta. Ako postoji granica rasta, mora postojati i granica pada.

Grafikon 6. $D P(\mathrm{u} \%)$ i godišnji prirast $D P(\mathrm{u}$ p. p.) BSFBiH Q4 2000 - Q4 2011. g. (Model 6)

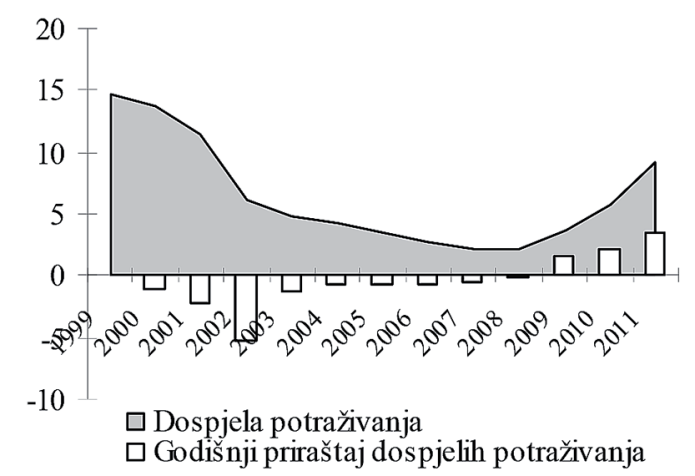

Izvor: www.abrs.ba i www.fba.ba (pristupljno 19.07.2012. g.)

Grafikon 7. LK vs. DP, (Model 7) BSFBiH Q4 2000 - Q4 2011. g.

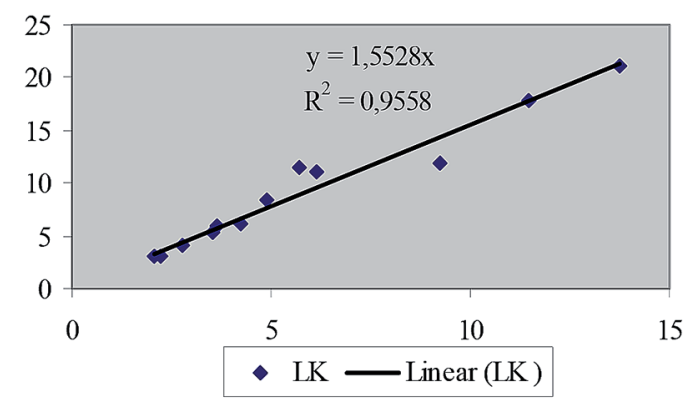

Izvor: Ibid. (obradio autor).
Promjena $u$ strukturi potraživanja po kreditnim instrumentima može označavati promjenu poslovne strategije. A promjena DP i promjena u veličini njihovog prirasta (rasta/ pada) indirektno označava promjenu u kvalitetu kreditnog portfolia. Ova promjena u stanju je da odredi kvalitet potraživanja $(L K)$ preciznije nego što se to radi preko klasifikacije kredita. Ako se izostavi reprogramiranje i refinansiranje kredita, kao vještački, ali zakonit, oblik smanjenja dospjelih potraživanja, onda su $D P$ zbog manje diskrecije u njihovom bilansiranju pouzdaniji indikator kvaliteta kredita od $L K$.

Između DP i $L K$ postoji izuzetno jaka inverzna korelacija (Grafikon 7). Model je predstavljen kao $L K=1,55 D P$ (Model 7). Prema njemu $95 \%$ varijabiliteta $L K$ objašnjava promjena $D P$. Model se približava savršeno linearnom. Promjena $D P$ za 1 p.p. povećava $L K$ za 1,5 p. p. U određivanju kvaliteta kreditnog portfolia $D P$ se može koristiti kao zamjena (proxy) za LK. $P$ vrijednost koeficjenta nagiba modela teže nuli. Model sa vremenskim pomakom $(L K=2,49+D P(-1))$ je lošija interpretacija veze. $R^{2}$ je manji, 0,67 , a slobodni član ima visoku $p$ vrijednost, 0,14 . (Model 8).

\section{Bruto domaći proizvod}

Najočiglednija manifestacija rasta proizvodnih snaga je BDP s.r. Rast je ekvivalentan ekonomskoj ekpanziji. Ona se odvija u uslovima rasta bankarskog kredita. Karakteristika ove faze ekonomskog ciklusa je nizak nivo $L K$ i nizak udjel dužnika u difoltu. Za pad konjukture se veže pogoršanje kreditnog portfolia i prelaz (migracija) kredita iz više u nižu kategoriju aktive. $B D P$ s.r. u periodu od 2003 - 2011. g. se kretao (Tabela 2) od 13,4\% do $-2,9 \%$, a $L K$ od $3,0 \%$ do $11,8 \%$. Vremensku seriju kvari podatak za 2009. g. - nivo $L K$ ne odgovara nivou BDP s.r. Kada se vremenske serije koriguju, izostavljanjem podataka za 2009. g., regresioni model je vrlo precizan (Grafikon 8, Model 9); 93\% varijabiliteta LK je objašnjeno sa variranjem $B D P$ s.r. Veza između varijabli, očekivano inverzna, vrlo je jaka, sa koeficjentom korelacije od - 0,98. Rast/ pad $B D P$ za jedan p.p. povećava/smanjuje $L K$ za 0,788 p.p. Prema prostom linearnom regresionom modelu $B D P$ s.r. od $0 \%$ odgovara nivou $L K$ od 13,2. Ako je BDP s.r. - $5 \% L K$ su 


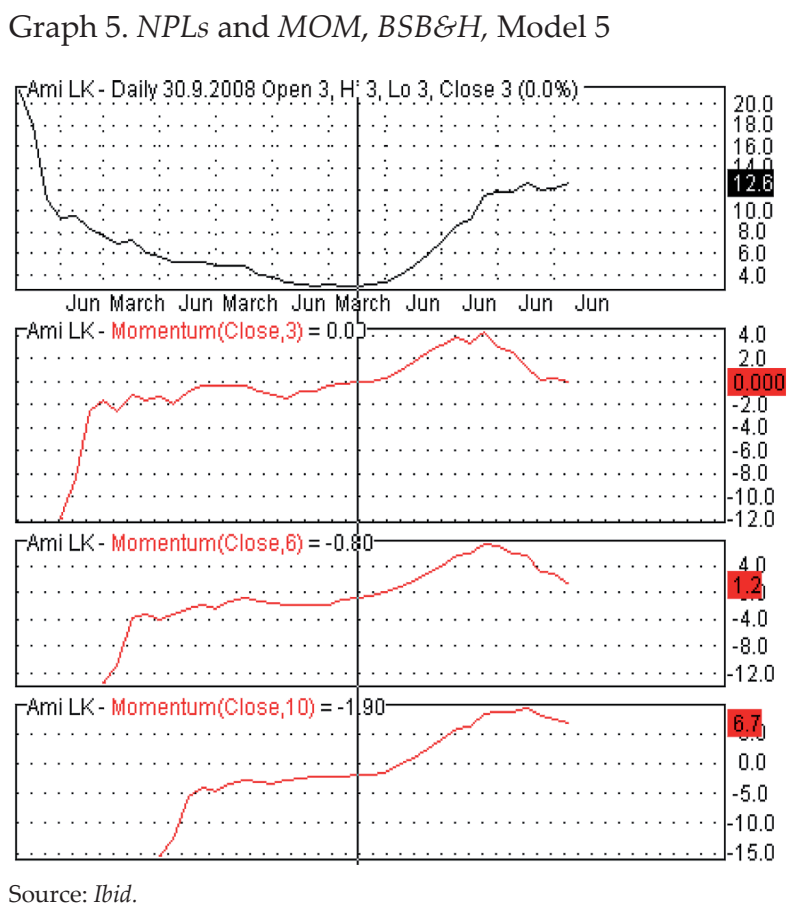

\section{Matured Receivables}

According to a very rough division, receivables in respect of loans are classified into: receivables in respect of loan principal, receivables in respect of leasing, and matured receivables. In $2000 M R$ was $13.74 \%$ (Graph 6). Since 2004 the momentum of the declining $M R$ trend has weakened.

After a rapid decline, in 2002, by 5.3 p.p. compared to 2001, in $2004 M R$ decreased by only 0.6 p.p. A similar standstill in the decline of $M R$ is visible in the subsequent three years (until 2007), whereas in 2008 the annual drop in $M R$ amounted to just -0.1 p.p. Having reached the limit to their decline, for the first time in 9 years $M R$ started to grow. The annual growth of $M R$ in 2009, 2010, and 2011 was 1.5 p.p., 2.1 p.p. and 3.5 p.p. respectively. According to the annual growth/drop of $M R$, the increase in $M R$ which occurred for the first time in 2009 could have been anticipated/foreseen already based on the slowed down decline of $M R$ in 2004 (Model 6). Limits to growth are a familiar concept in social and other sciences. Everything develops, grows/declines and reaches its maximum, or minimum, which is, respectively, followed by a decline, or growth. If there is a limit to growth, there must be a limit to decline.
Graph 6. $M R$ (in \%) and annual $M R$ growth (in p.p.) BSFBEH Q4 2000 - Q4 2011 (Model 6)

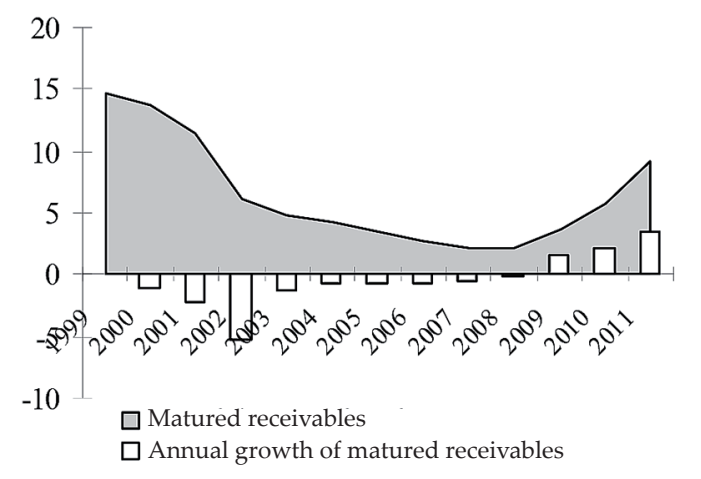

Source: www.abrs.ba and www.fba.ba (accessed on 19.07.2012)

Graph 7. NPLs vs. MR (Model 7) BSFBEH Q4 2000 - Q4 2011

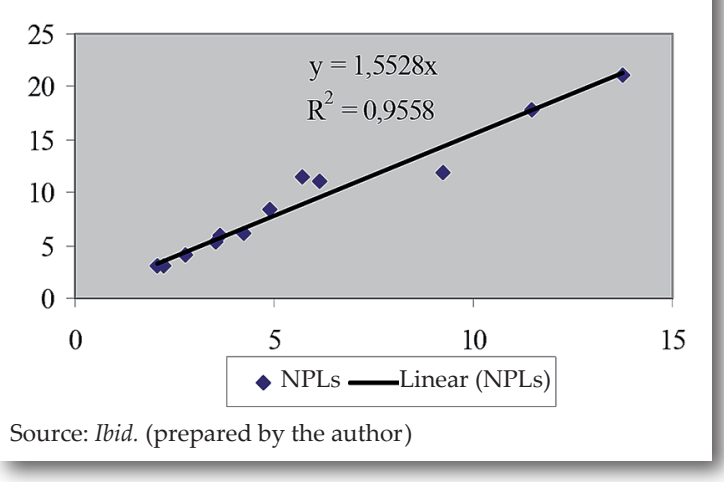

A change in the structure of receivables in respect of credit instruments may signify a change in the business strategy. On the other hand, a change in $M R$ and a change in the size of their growth/decline indirectly signify a change in the credit portfolio's quality. By interpreting this change one is able to determine the quality of receivables (NPLs) more precisely than by loan classification. If we leave out rescheduling and refinancing of loans, as an artificial yet legitimate form of reducing matured receivables, then $M R$, due to the lower discretion in their balancing, serve as a more reliable indicator of loans' quality than NPLs.

There is an extremely powerful inverse correlation between MR and NPLs (Graph 7). The model is set up as NPLs=1.55MR (Model 7). According to it, $95 \%$ of NPLs variability is explained by the change in $M R$. The model approaches a perfectly linear one. The change in $M R$ by 1 p.p. increases NPLs by 1.5 p.p. In determining the quality of the credit portfolio, $M R$ can be used as a proxy for NPLs. $P$ values of the model's skewness coefficient approach zero. The model with a time lag (NPLs-2.49+MR(-1)) is a poorer interpretation 
$17,1 \%$, dok BDP s.r. od $10 \%$ odbacuje $L K$ od 5,3 (tabela 4). Veća preciznost opisa veze između varijabli može se postići upotrebom kvartalnih podataka o BDP s.r., ali zvanična statistika ne publikuje te podatke. Ipak, i na bazi očekivanog $B D P$ s.r., prema karakteristikama sagrađenog regresionog modela, mogu se odrediti krajnje godišnje vrijednosti $L K$. Model je vrlo pouzdan, $p$ vrijednosti za ocjenu koeficijenata modela teže nuli (tabela 3).

Međutim, regresioni model sa jednim vremenskim pomakom, za period 2003-2011. g., kojiuključuje2009.g., ima sasvim zadovoljavajuće karakteristike; $R^{2}$ od 0,744 i $p$ vrijednosti koeficjenata modela koje teže nuli. Specifikacija modela je: $L K=-0,52^{*} B D P$ s.r. $(-1)+10,23$ (Model 10). Povećanje BDP od $1 \%$, koje smanjuje $L K$ za oko pola p.p., ima punu ekonomsku logiku. Model sa vremenskim pomakom daje $L K$ od 10,23 za BDP s.r. od 0\%. Standardna greška modela je 1,9.

Tabela 2. BDP s. r. i $L K$

\begin{tabular}{|l|r|r|r|r|r|r|r|r|r|}
\hline & \multicolumn{1}{|c|}{2003.} & \multicolumn{1}{|c|}{2004.} & 2005. & \multicolumn{1}{|c|}{2006.} & 2007. & 2008. & 2009. & 2010. & \multicolumn{1}{|c|}{2011.} \\
\hline BDP s.r. & 5,3 & 8,6 & 8,0 & 12,3 & 12,9 & 13,4 & $-2,9$ & 2,2 & 3,6 \\
\hline LK & 8,4 & 6,1 & 5,3 & 4,0 & 3,0 & 3,1 & 5,9 & 11,4 & 11,8 \\
\hline
\end{tabular}

Izvor: www.cbbh.ba (pristupljeno 10.10.2012. g.) (obradio autor)

Tabela 3. Ocjena parametara regresionog modela (2003-2011), bez 2009, Model 9

\begin{tabular}{|l|r|r|r|r|}
\hline & $\begin{array}{c}\text { Ocjena } \\
\text { koeficjenta }\end{array}$ & $\begin{array}{c}\text { Standardna } \\
\text { greška }\end{array}$ & $\begin{array}{c}\mathrm{T} \\
\text { statistika }\end{array}$ & $\begin{array}{c}\mathrm{P} \\
\text { vrijednost }\end{array}$ \\
\hline Slobodni član & 13,17 & 0,78 & 16,88 & 0,000003 \\
\hline Koeficjent nagiba & $-0,79$ & 0,08 & $-9,32$ & 0,000086 \\
\hline
\end{tabular}

Izvor: Ibid.

Grafikon 8. LK vs. BDP s.r., (2003-2011), bez 2009, Model 9

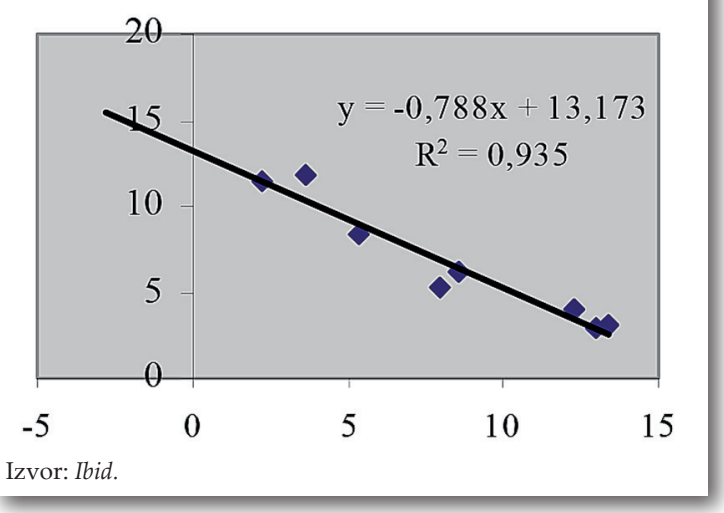

\section{Kamatni raspon}

Sa rastom $L K$ dolazi do širenja KR. Banke, da bi nadoknadile gubitke na kreditnom portfoliu, moraju privući dodatni depozitni potencijal. Depoziti, kao i svaka druga roba, imaju cijenu. Ponuda depozita raste sa rastom pasivnih kamatnih stopa, pa rast $L K$ prati, u prosjeku, stalno viši nivo pasivnih kamatnih stopa. Njihov rast se prenosi na rast cijena bankarskih agregata - kamatnih stopa na kredite. Tako se odvija teorijski proces usklađivanja cijena bankarskih resursa i agregata kada $L K$ rastu.

Teorija i praksa nisu uvijek usklađeni, procesi u bankarskim knjigama se ne moraju odvijati po teorijskim pretpostavkama niti po empirijskom obrascu. $K R$ u $B S B i H$, nakon početka globalne ekonomsko-finansijske krize, se ne koriguju neprekidno po teorijsko/praktičnom modelu usklađivanja aktivnih i pasivnih kamatnih stopa. U periodu od oktobra 2008. g. (bankrot američke investicione banke Lehman Brothers), pa sve do kraja 2012. g., nismo utvrdili, za cijeli analizirani vremenski interval, jedinstvenu

Tabela 4. Vrjednosti $L K$ na osnovu regresionog modela i očekivanog $B D P$ s.r.

\begin{tabular}{|c|c|c|c|c|c|c|c|c|c|c|c|c|c|c|}
\hline $\begin{array}{l}\text { BDP s.r. } \\
(\mathrm{u} \%)\end{array}$ & -5 & -4 & -3 & -2 & -1 & 0 & 1 & 2 & 3 & 4 & 5 & & 9 & 10 \\
\hline$L K$ & 17,1 & 16,3 & 15,5 & 14,7 & 14,0 & 13,2 & 12,4 & 11,6 & 10,8 & 10,0 & 9,2 & & 6,1 & 5,3 \\
\hline
\end{tabular}

i r e k t n u linearnu vezu između rasta $L K$ i $K R$.

Od Q1 2009 Izvor: Ibid.

do Q2 2010, rast $L K$ i rast

Regresioni model u kojem su povezani $L K \mathrm{u}$ tekućem periodu i BDP s.r. iz prethodnog perioda (regresioni model sa vremenskim pomakom) nije upotrebljiv za predviđanje $L K$. U modelu $L K=c(1)+c(2)^{*} B D P$ s.r. $(-1), R^{2}$ je svega 0,136 .
$K R$ se odvija istovremeno. Rast $L K$ za 1 p.p. povećava $K R$ za 0,26 p.p. (grafikon 9). U modelu sa vremenskim pomakom od jednog kvartala jačina veze je identična $\left(R^{2}=0,9\right)$, uz napomenu da je on ipak bliži realnosti. Do usklađivanje $K R$ 
of this correlation. $\mathrm{R}^{2}$ is lower, at 0.67 , whereas the random variable has a high $p$ value of 0.14 (Model 8).

\section{Gross Domestic Product}

The most obvious manifestation of the increased production capacities is the GDP g.r. The growth is equivalent to the economic expansion. It takes place in the circumstances of intensified bank lending. What characterizes this stage in the economic cycle is the low level of NPLs and a low share of debtors in default. On the other hand, what marks a cyclical downswing is the deterioration of the credit portfolio and the migration of loans from higher into lower categories of assets. In the period 2003-2011 GDP g.r. ranged from $13.4 \%$ to $-2.9 \%$ (Table 2 ) and NPLs from $3.0 \%$ to $11.8 \%$. The time series is spoiled by the data for 2009 - the level of NPLS does not correspond to the GDP g.r. After the time series get revised, by omitting the data for 2009, the regression model is very precise (Graph 8, Model 9); 93\% of the NPLs variability is explained by means of the variations in GDP g.r. The correlation between variables, inverse as expected, is rather strong, the correlation coefficient a mounting to -0.98 . The growth/decline of GDP by one p.p. increases/decreases NPLs by 0.788 p.p. According to the simple linear regression model, GDP g.r. of $0 \%$ corresponds to the NPLs level of 13.2. If the GDP g.r. is $-5 \%$, the NPLs are $17.1 \%$, whereas the GDP g.r. of $10 \%$ corresponds to the NPLs of 5.3 (Table 4). Higher precision in describing the correlation between the variables can be achieved by using quarterly data on GDP g. $r$, but the official statistics does not publish such data. However, even on the basis of the expected GDP g.r, according to the characteristics of the constructed regression model, one can determine the end-of-the-year values of NPLs. The model is highly reliable; $p$ values for the assessment of the model's coefficients approach zero (Table 3 ).
Table 3. Assessment of regression model parameters (20032011), without 2009, Model 9

\begin{tabular}{|l|r|r|r|r|} 
& \multicolumn{1}{|c|}{$\begin{array}{c}\text { Ratio } \\
\text { estimate }\end{array}$} & \multicolumn{1}{c|}{$\begin{array}{c}\text { Standard } \\
\text { error }\end{array}$} & T statistics & P value \\
\hline Random variable & 13.17 & 0.78 & 16.88 & 0.000003 \\
\hline $\begin{array}{l}\text { Skewness } \\
\text { coefficient }\end{array}$ & -0.79 & 0.08 & -9.32 & 0.000086 \\
\hline
\end{tabular}

source: Ibid.

Graph 8. NPLs vs. GDP g.r., (2003-2011), without 2009, Model 9

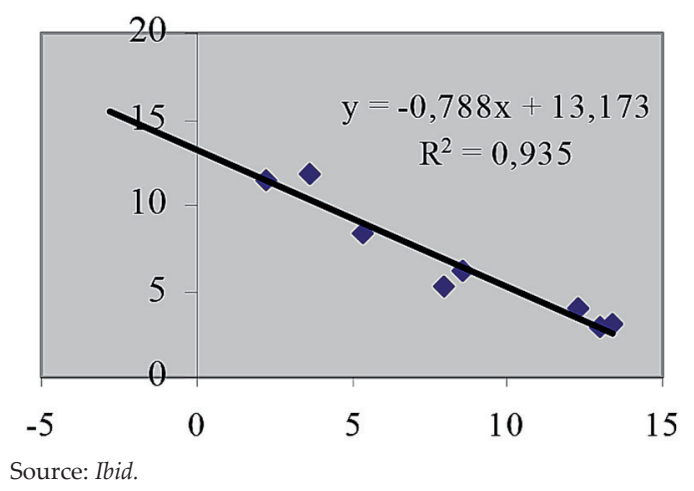

Table 4. NPLs values based on the regression model and the expected GDP g.r.

\begin{tabular}{|l|r|r|r|r|r|r|r|r|r|r|r|r|r|r|}
\hline $\begin{array}{l}\text { GDP g.r. } \\
\text { (in \%) }\end{array}$ & -5 & -4 & -3 & -2 & -1 & 0 & 1 & 2 & 3 & 4 & 5 & & 9 & 10 \\
\cline { 1 - 12 } NPLs & 17.1 & 16.3 & 15.5 & 14.7 & 14.0 & 13.2 & 12.4 & 11.6 & 10.8 & 10.0 & 9.2 & & 6.1 & 5.3 \\
\hline
\end{tabular}

Source: Ibid.
Table 2. GDP g.r. and NPLs

\begin{tabular}{|l|r|r|r|r|r|r|r|r|r|}
\hline & \multicolumn{1}{|c|}{2003} & \multicolumn{1}{|c|}{2004} & \multicolumn{1}{|c|}{2005} & \multicolumn{1}{|c|}{2006} & \multicolumn{1}{|c|}{2007} & \multicolumn{1}{c|}{2008} & \multicolumn{1}{c|}{2009} & 2010 & \multicolumn{1}{c|}{2011} \\
\hline GDP g.r. & 5.3 & 8.6 & 8.0 & 12.3 & 12.9 & 13.4 & -2.9 & 2.2 & 3.6 \\
\hline NPLs & 8.4 & 6.1 & 5.3 & 4.0 & 3.0 & 3.1 & 5.9 & 11.4 & 11.8 \\
\hline
\end{tabular}

Source: www.cbbh.ba (accessed on 10.10.2012) (prepared by the author) 
i $L K$ rjetko dolazi istovremeno, $\mathrm{u}$ istom kvartalu; promjeni $K R$ bi trebala prethoditi promjena $L K$.

Grafikon 9. Linearni regresioni model $K S=f(L K)$, Q1 2009-Q2 2010

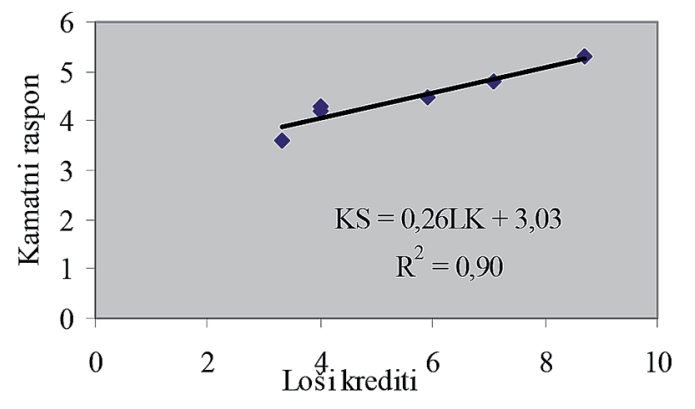

Izvor: Ibid.

Grafikon 10. Linerni regresioni model $L K=f^{-1}(K S)$, Q1 2009 - Q2 2010, Model 11

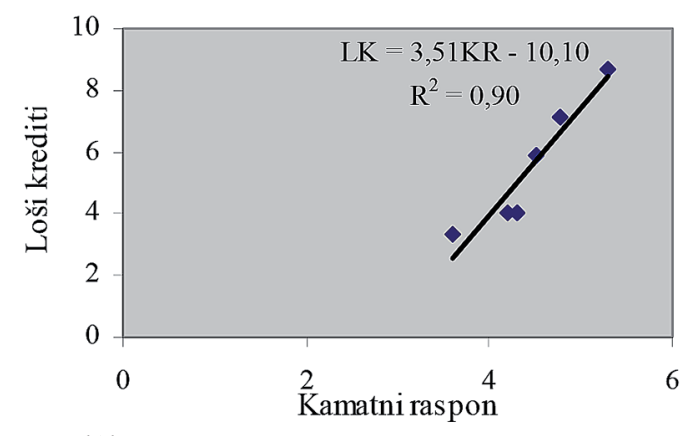

Izvor: Ibid.

Inverzijom linearnog modela (grafikon 10, Model 11) LK se postavlja u funkciju zavisno promjenljive. Inverzna funkcija, iako odudara od stvarne/empirijske uzročno posljedične veze između $L K$ i $K R$, po kojoj $L K$ utiču na $K R$, a ne obratno, ipak odgovara na pitanje koja vrijednost $L K$ odgovara očekivanoj i/ili zadatoj i/ili izmjerenoj vrijednosti $K R$.

Ako je očekivani $K R 5$ p.p. $L K$ će biti $7,45 \%$. To je jedan oblik tumačenja inverzne funkcije/modela. Na osnovnu istog modela (grafikon 10) možemo zaključivati i ovako: ako smo izolovali direktnu linearnu vezu između $L K$ i $K R, \mathrm{i}$ ako je $K R 5 \%$, a $L K$ se značajno razlikuje od $7,45 \%$ onda je $L K$ podcjenjen/precjenjen. Podrazumjeva se da $L K$ ne može biti negativan. Zato je za vrijednosti $K R$ ispod 2,87 inverzni model neupotrebljiv za predviđanje $L K$. Linearni regresioni model, pored visokog koeficjenta korelacije, ima i odlične ocjenjene vrijednosti koeficjenata modela. $P$ vrijednosti su 0,000257 odnosno 0,0038 (Tabela 5). U Modelu 11 (Tabela 6) hipotezu da su koeficjenti jednaki nuli odbacujemo sa vjerovatnoćom da smo pogriješili od 1,7\%, odnosno $0,3 \%$.

Tabela 5. Ocjena parametara modela $K R=0,26 L K+3,03$, Q1 2009 - Q2 2010.

\begin{tabular}{|l|r|r|r|r|}
\hline & $\begin{array}{c}\text { Ocjena } \\
\text { koeficjenta }\end{array}$ & $\begin{array}{c}\text { Standardna } \\
\text { greška }\end{array}$ & $\begin{array}{c}\mathrm{T} \\
\text { statistika }\end{array}$ & $\begin{array}{c}\mathrm{P} \\
\text { vrijednost }\end{array}$ \\
\hline $\begin{array}{l}\text { Slobodni } \\
\text { član }\end{array}$ & 3,03 & 0,25 & 12,22 & 0,000257 \\
\hline $\begin{array}{l}\text { Koeficjent } \\
\text { nagiba }\end{array}$ & 0,26 & 0,04 & 6,02 & 0,003819 \\
\hline
\end{tabular}

Izvor: Ibid.

Tabela 6. Ocjena parametara modela, $L K=3,51 K R-10,1, \mathrm{Q} 12009$ - Q2 2010, Model 11

\begin{tabular}{|l|r|r|r|r|}
\hline & $\begin{array}{c}\text { Ocjena } \\
\text { koeficjenta }\end{array}$ & $\begin{array}{c}\text { Standardna } \\
\text { greška }\end{array}$ & $\begin{array}{c}\mathrm{T} \\
\text { statistika }\end{array}$ & $\begin{array}{c}\mathrm{P} \\
\text { vrijednost }\end{array}$ \\
\hline $\begin{array}{l}\text { Slobodni } \\
\text { clan }\end{array}$ & $-10,10$ & 2,61 & $-3,88$ & 0,017907 \\
\hline $\begin{array}{l}\text { Koeficjent } \\
\text { nagiba }\end{array}$ & 3,51 & 0,58 & 6,03 & 0,003819 \\
\hline
\end{tabular}

Izvor: Ibid.

Čvrsta direktna veza između varijabli ne postoji samo $\mathrm{u}$ jednom malom vremenskom periodu, u trajanju od godinu i po dana, između 2009. g. i 2010. g. Od Q3 2004, pa sve do Q3 2008 traje takođe izuzetno visok stepen podudarnosti u kretanju LK i KR. Model 12 (tabela 7) ima visok $R^{2}, 0,83$, a koeficjent nagiba je idealan ( $p$ vrijednost je nula). Međutim, vjerovatnoća da smo odbacili nultu hipotezu po kojoj je slobodan član jednak nuli je 15\% ( $p$ vrijednost 0,149). Povećanje KR za 1 p.p. povećava $L K$ za 0,692 .
Tabela 7. Ocjena parametara modela $L K=0,692+0,797 K R$, Q3 2004 - Q3 2008, Model 12

\begin{tabular}{|l|r|r|r|r|r|}
\hline & $\begin{array}{c}\text { Ocjena } \\
\text { koeficijenta }\end{array}$ & $\begin{array}{c}\text { Standardna } \\
\text { greška }\end{array}$ & $\begin{array}{c}\text { T } \\
\text { statistika }\end{array}$ & $\begin{array}{c}\text { P } \\
\text { vrijednost }\end{array}$ & $\begin{array}{c}\text { Standardna } \\
\text { greška } \\
\text { modela }\end{array}$ \\
\hline $\begin{array}{l}\text { Slobodni } \\
\text { član }\end{array}$ & 0,692 & 0,455 & 1,522 & 0,149 & 0,97 \\
\hline $\begin{array}{l}\text { Koeficjent } \\
\text { nagiba }\end{array}$ & 0,797 & 0,092 & 8,680 & 0,000 & \\
\hline
\end{tabular}

Izvor: Ibid.
Pohvala Modelu 12 nestaje kad se preko njega pokuša doći do visokih vrijednosti $L K$. $K R$ od 10 daje $L K$ od svega $8 \%$. Iako se prostire $\mathrm{u}$ dugom vremenskom periodu, izvan njega model nema ekonomsko opravdanje. KR nije jedina varijabla koja određuje $L K$.

Opet prividno odličan model, visok $R^{2}$, 
The standard error of the model is 1.9.

\section{Interest Rate Spread}

The growth of NPLS is accompanied by the widening of the IRS. In order to compensate for the losses in their credit portfolio, banks must attract additional deposit potential. Deposits, like all other goods, have a price. The supply of deposits increases as the passive interest rates grow, which is why a growth of NPLs is, on average, accompanied by a permanently higher level of passive interest rates. Their increase subsequently brings up the prices of the banking aggregates - i.e. interest rates on loans. This is the theoretical process of harmonizing the prices of bank resources and aggregates when the NPLs grow.

Yet, the theory and practice are not always harmonized; the processes in the banking books do not necessarily follow theoretical assumptions or empirical patterns. Since the outbreak of the global economic and financial crisis, IRS in the $B S B \mathcal{E} H$ have not been incessantly revised according to the theoretical/practical model of harmonizing active and passive interest rates. In the period since October 2008 (bankruptcy of the US investment bank Lehman Brothers) until the end of 2012, we have not managed to establish, for the entire analyzed time interval, a unique direct linear correlation between the growth of NPLS and IRS.

From Q1 2009 to Q2 2010, the growth of NPLs and the growth of IRS were concurrent. The growth of NPLs by 1 p.p. increased the IRS by 0.26 p.p. (Graph 9). In the model with a time lag by one quarter, the strength of the correlation is identical $\left(R^{2}=0.9\right)$, with a note worth mentioning that it is still closer to reality. IRS and NPLS are rarely harmonized at the same time, in the same quarter; a change in the IRS should be preceded by a change in the NPLS.

Graph 9. Linear regression model $I R=f(N P L s)$, Q1 2009-Q2 2010

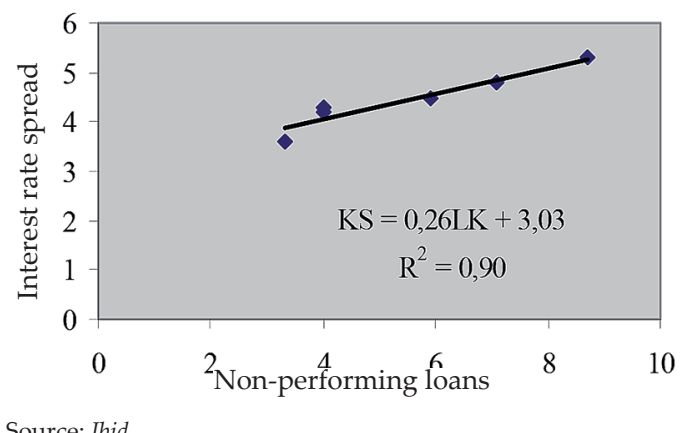

Graph 10. Linear regression model $N P L s=f^{-1}(I R)$, Q1 2009 - Q2 2010, Model 11

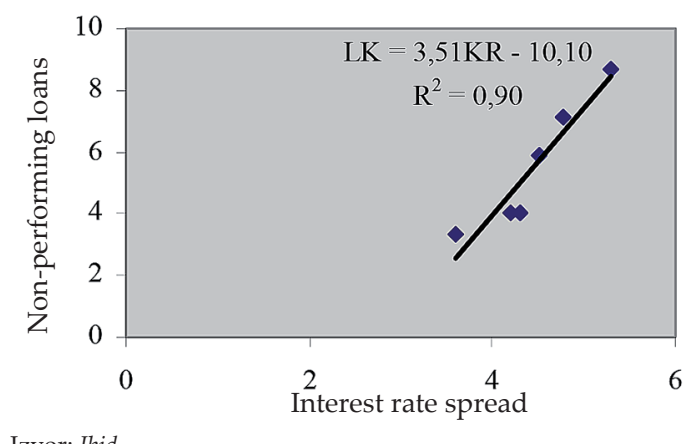

By means of the linear model inversion (Graph 10, Model 11) NPLs are set in the function of a dependent variable. Inverse function, although deviating from the real/ empirical cause and effect relation between NPLS and IRS, according to which NPLs affect $I R S$, and not the other way around, still answers the question which value of NPLs responds to the expected and/or given and/or measured value of IRS.

If the expected IRS is 5 p.p. NPLs will be $7.45 \%$. This is one way to interpret the inverse function/ model. Based on the same model (Graph 10), we can also draw the following conclusion: if we isolated a direct linear correlation between NPLS and IRS, and if IRS is 5\%, and NPLS substantially deviate from $7.45 \%$, then the NPLS are underestimated/overestimated. It is taken that NPLs cannot be negative. This is why, for the IRS values below 2.87, the inverse model is useless when it comes to NPLs forecasting. The linear regression model, in addition to the high correlation coefficient, also has the excellent estimated values of the model's coefficients. $P$ values are 0.000257 and 0.0038 (Table 5). In Model 11 (Table 6) we rejected the hypothesis that coefficients equal zero with the probability of error amounting to $1.7 \%$, and $0.3 \%$.

Table 5. Assessment of model parameters IRS=0.26NPLs+3.03, Q1 2009-Q2 2010.

\begin{tabular}{|c|c|c|c|c|}
\hline & $\begin{array}{c}\text { Ratio } \\
\text { estimate }\end{array}$ & $\begin{array}{l}\text { Standard } \\
\text { error }\end{array}$ & $\begin{array}{c}\mathrm{T} \\
\text { statistics }\end{array}$ & $\mathrm{P}$ value \\
\hline $\begin{array}{l}\text { Random } \\
\text { variable }\end{array}$ & 3.03 & 0.25 & 12.22 & 0.000257 \\
\hline $\begin{array}{l}\text { Skewness } \\
\text { coefficient }\end{array}$ & 0.26 & 0.04 & 6.02 & 0.003819 \\
\hline
\end{tabular}

Source: Ibid. 
viši nego u prethodnom modelu, niska $p$ vrijednost ocjene koeficijenata modela, se dobija transformacijom prethodnog modela $\mathrm{u}$ model sa vremenskim pomakom (Tabela 8, Model 13). Osnovne karakteristike modela su visok koeficjent determinacije $\left(R^{2}=0,87\right)$ i $p$ vrijednost za koeficjente modela ispod nule. Problem sa modelom je $\mathrm{u}$ tome što njegovom ekstrapolacijom dobijaju potpuno nelogične i nemoguće vrijednosti. Na primjer, za vrijednost KR od 13 p.p. LK je svega $10 \%$, a KR od 13 p.p. je nemoguć događaj. $K R$ ne može objasniti visoke vrijednosti $L K$. Model može funkcionisati samo u domenu izuzetno niskih $L K$. On ima ograničenu upotrebu.

internog i/ili eksternog šoka i realno procjenjene vrijednosti bankarskih aktiva, na kraju 2013. g. $L K$ bi trebao biti $12,07 \%$, a krajem 2014. g. $9,82 \%$. Polinom je dobra i matematička i logička projekcija razvoja $L K$, jer i prema empirijskim podacima, $\mathrm{u}$ intervalu između $12 \%$ i $13 \%$ LK dostiže lokalni maksimum. Zaustavljanje rasta $L K$ odgovara konceptu granica rasta i principu da kod svake pojave nakon intezivnog perioda rasta nastupa vrijeme sporijeg rasta, prestanka rasta, i opadanja.

U bankarskim sistemima koji se odlikuju rapidnim padom $L K$, a kojem prethodi i/ili ga prati kreditna ekspanzija, polinom drugog reda je najbolja teorijska aproksimacija kretanja $L K$. To isto je polinom drugog reda $u$ periodu snažnog rasta $L K$. Pored toga on je i koristan alat za kratkoročno predviđanje $L K$. Usvajanje vrlo rigorozne, i izuzetno optimistične pretpostavke, da će $L K$ sljediti i $\mathrm{u}$ srednjem roku model kreiran polinom (grafikon 12), daje u 2016. g. $L K \mathrm{u}$ intervalu između 5\% i 3\%. U tom intervalu bi trebao biti formiran otpor daljem padu LK. Nakon

\section{Modeliranje $L K$ preko vremenske serije}

$L K$ smo modelirali, kao polinom drugog reda, i to za dva perioda. $U$ prvom periodu, on obuhvata pad LK (Q2 2003 - Q3 2008), polinom objašnjava 98\% varijabiliteta LK (grafikon 11, Model 14). Produžetak/ekstrapolacija modela daje buduće vrijednosti koje značajno odstupaju od stvarnih/empirijskih vrijednosti $L K$. Tako je u Q3 2012 teorijska/modelirana vrijednost $L K 5,36 \%$, a stvarna $12,7 \%$. Polinom je odlična teorijska aproksimacija $L K$ tokom njegovog pada (standardna greška modela 0,08 ), ali on nije model podesan za dalje predviđanje $L K$.

Jedan, potpuno različit polinom, (Grafikon 12, Model 15), ali sa približno jednakim stepenom tačnosti kao i prethodni $\left(R^{2}\right.$ $\approx 0,97 \approx 0,98$ ) opisuje ponašanje $L K \mathrm{u}$ periodu rasta (Q3 2008 - Q3 2012). On se može upotrjebiti i za predviđanje kretanje $L K$ u bliskoj budućnosti (standardna greška modela 0,26). Pod pretpostavkama odsustva nekog jakog zaustavljanja pada $L K$ polinom drugog reda nije prikladan za dalje predviđanje kretanja $L K$, osim ako se istorija $\mathrm{u}$ apsolutno istom obliku ne ponovi, što je, ili nemoguć događaj, ili je događaj izuzetno niske vjerovatnoće, ili je događaj koji će se ponoviti u nekoj dalekoj prošlosti. Optimizam ovoga modela je posljedica njegove strukture. On kao nezavisno promjenljivu varijablu ima sam vrijeme, tj. protok vremena, $u$ kojem mogu, ali najčešće nisu, zastupljene i predstavljene fundamentalne bankarske, ili ekonomske varijable. Polinome razdvaja period stagnacije $L K$, vrijeme $\mathrm{u}$ kojem se formira otpor daljem padu $L K$. Formiranje nivoa otpora, alata tehničke analize, omogućava razdvajanje vremenske serije i formiranje polinoma, koji, svaki u svom dijelu, odlično aproksimiraju kretanje $L K$. Nivo otpora označava prekid jednog trenda i početak drugog trenda. Koncept tehničke analize je, u jedinstvu, isprepleten sa analizom vremenske serije. 
Table 6. Assessment of model parameters NPLs=3.51KR-10.1, Q1 2009 - Q2 2010, Model 11

\begin{tabular}{|l|r|r|r|l|}
\hline & \multicolumn{1}{|c|}{$\begin{array}{c}\text { Ratio } \\
\text { estimate }\end{array}$} & \multicolumn{1}{c|}{$\begin{array}{c}\text { Standard } \\
\text { error }\end{array}$} & \multicolumn{1}{c|}{$\begin{array}{c}\mathrm{T} \\
\text { statistics }\end{array}$} & P value \\
\hline $\begin{array}{l}\text { Random } \\
\text { variable }\end{array}$ & $-10,10$ & 2,61 & $-3,88$ & 0,017907 \\
\hline $\begin{array}{l}\text { Skewness } \\
\text { coefficient }\end{array}$ & 3,51 & 0,58 & 6,03 & 0,003819 \\
\hline
\end{tabular}

Source: Ibid. and impossible values. For instance, the IRS of 13 p.p. corresponds to NPLs of only $10 \%$, and IRS of 13 p.p. is an impossible event. IRS cannot explain the high values of NPLs. The model can only function in the domain of extremely low NPLs. Therefore, it has a limited usability.

\section{A strong direct correlation} between the variables does not exist only for a short time period of one and a half years, from 2009 to 2010. From Q3 2004 to Q3 2008 there is a high level of correlation in the movements of NPLs and IRS. Model 12 (Table7) has a high $\mathrm{R}^{2}$ of 0.83 , and the skewness coefficient is ideal ( $p$ value equals zero). However, there is a $15 \%$ probability that we discarded the zero hypothesis according to which the random variable equals zero ( $p$ value is 0.149 ). The increase of IRS by 1 p.p. increases NPLs by 0.692 .

Source: Ibid.

Table 8. Assessment of model parameters

NPLs=0.929+0.699IRS(-1), Q4 2004-Q3 2008, Model 13

\begin{tabular}{|l|r|r|r|r|r|}
\hline & \multicolumn{1}{|c|}{$\begin{array}{c}\text { Ratio } \\
\text { estimate }\end{array}$} & \multicolumn{1}{|c|}{$\begin{array}{c}\text { Standard } \\
\text { error }\end{array}$} & $\begin{array}{c}\text { T } \\
\text { statistics }\end{array}$ & P value & $\begin{array}{r}\text { Standard } \\
\text { error of the } \\
\text { model }\end{array}$ \\
\hline $\begin{array}{l}\text { Random } \\
\text { variable }\end{array}$ & 0,929 & 0,361 & 2,575 & 0,022 & \multirow{2}{*}{0,97} \\
\cline { 1 - 4 } $\begin{array}{l}\text { Skewness } \\
\text { coefficient }\end{array}$ & 0,699 & 0,072 & 9,753 & 0,000 & \\
\hline
\end{tabular}

\section{NPLs Modeling Through a Time Series}

In the form of a second order polynomial we modeled NPLs for two periods. In the first period covering the decline of NPLs (Q2 2003-Q3 2008), the polynomial explains $98 \%$ of the NPLS

Table 7. Assessment of model parameters NPLs $=0.692+0.797$ IRS, Q3 2004-Q3 2008, Model 12

\begin{tabular}{|l|r|r|r|r|r|}
\hline & \multicolumn{1}{|c|}{$\begin{array}{c}\text { Ratio } \\
\text { estimate }\end{array}$} & \multicolumn{1}{|c|}{$\begin{array}{c}\text { Standard } \\
\text { error }\end{array}$} & $\begin{array}{r}\text { T } \\
\text { statistics }\end{array}$ & P value & $\begin{array}{c}\text { Standard } \\
\text { error of the } \\
\text { model }\end{array}$ \\
\hline $\begin{array}{l}\text { Random } \\
\text { variable }\end{array}$ & 0,692 & 0,455 & 1,522 & 0,149 & \multirow{2}{*}{0,97} \\
\cline { 1 - 4 } $\begin{array}{l}\text { Skewness } \\
\text { coefficient }\end{array}$ & 0,797 & 0,092 & 8,680 & 0,000 & \\
\hline
\end{tabular}

Source: Ibid.

The praise directed at Model 12 ends when we try to use it for reaching the high values of NPLS. IRS of 10 corresponds to NPLs of only $8 \%$. Although it encompasses a long time period, this model is not economically justified beyond it. IRS is not the only variable determining NPLs.

Again, a seemingly excellent model, with high $\mathrm{R}^{2}$, higher than in the previous model, and low $p$ value of the model's coefficients assessment, obtained by a transformation of the previous model into a model with a time lag (Table 8, Model 13). The main characteristics of the model are high determination coefficient $\left(\mathrm{R}^{2}=0.87\right)$ and $p$ values for the model's coefficients below zero. The problem with this model is that its extrapolation provides complete illogical variability (Graph 11, Model 14). The extension/extrapolation of the model provides future values that substantially deviated from the real/ empirical NPLs values. Thus, in Q3 2012 the theoretical/modeled value of NPLs was $5.36 \%$ and the actual one $12.7 \%$. The polynomial is an excellent theoretical approximation of NPLs during their decline (standard error of the model is 0.08 ), but it is not a model suitable for further forecasting of NPLS.

A completely different polynomial (Graph 12, Model 15), but with approximately the same accuracy level as the previous one $\left(R^{2}\right.$ $\approx 0.97 \approx 0.98$ ) describes the NPLs behavior in the period of growth (Q3 2008-Q3 2012). It can also be used to forecast the NPLs movements in the foreseeable future (standard error of the model is 0.26). Under the assumption of no strong internal and/or external shocks and realistically estimated value of bank assets, at the end of 2013 NPLs should amount to $12.07 \%$, and at the end of 2014 to $9.82 \%$. A polynomial is a sound mathematical and logical projection of the NPLSS development, because according to the empirical data, in the interval between $12 \%$ and $13 \%$ NPLS 
Grafikon 11. LK tokom pada, (Q3 2003 - Q3 2008), Model $14^{*}$

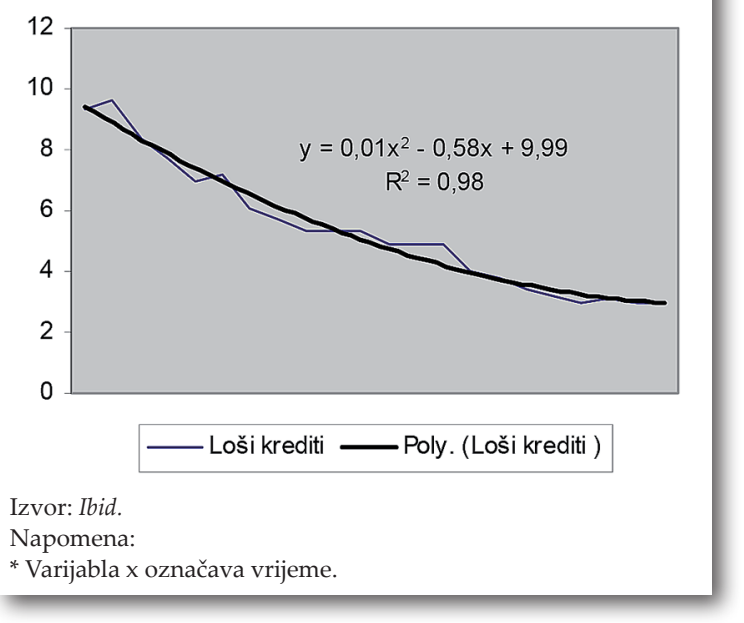

Grafikon 12. LK tokom rasta, (Q4 2008 - Q3 2012), Model 15*

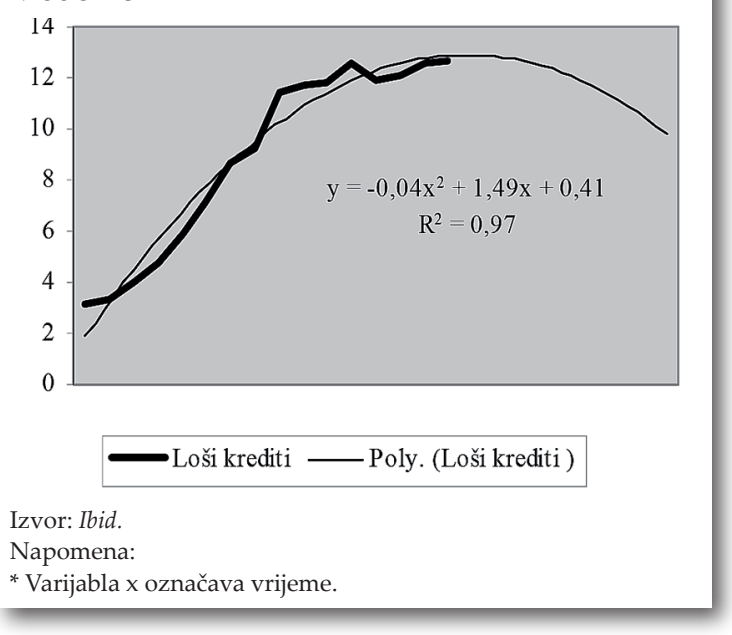

\section{Zaključak}

Upotrebom različitih metodologija, razvili smo 15 modela (tabela 9) za predviđanje LK. Hipoteze istraživanja su dokazane: 1) predviđanje $L K$ zahtjeva kombinovanje različitih metodologija 2) različitim periodima razvoja $L K$ odgovaraju različiti modeli za predviđanje 3) tehnička analiza je jedan od metoda/modela za predviđanje $L K$.

Vremenska serija $L K$ je vrlo varijabilna. $U$ periodu 2000 - 2012. g., minimalni $L K$ je 3\%. Maksimalna vrijednost $L K$ je $21,2 \%$ - dugački rep se formira $u$ desnom dijelu distribucije. Vjerovatnoća da će $L K$ uzeti ekstremno niske vrijednosti, ispod 3\% i ekstremno visoke vrijednosti, iznad $12,1 \%$, je $7,3 \%$ i $12,2 \%$ respektivno (Model 1). Najučestalije (41,5\%) su vrijednosti $L K$ između 3,1\% i 6\%. Aritmetička sredina serije $L K$ je $7,59 \%$, a medijana je 6,1\%.
Pomoću alata tehničke analize, linije trenda i nivoa podrške/otpora, se može predvidjeti promjena trenda $L K$. Linija trenda identifikuje mogućnost promjene trenda već u Q4 2007 i Q3 2008. (Model 2). Nivo podrške ili prilagođeno karakteristikama serije $L K$, nivo otpora od 3\% je formiran u Q2 2007 i traje sve do Q1 2009. Na osnovu formiranog nivoa otpora, već u drugoj polovini 2007. g. moglo se znati da će doći do promjene trenda i rasta $L K$ (Model 3).

Slične prediktivne sposobnosti imaju i impulsi (MOM) i stopa promjene (ROC). MOM 10 nagovještava promjenu trenda $L K$ kada se pad usporava na vrijednosti ispod 2 p.p., a MOM 6 na ispod 1 p.p. Najava preokreta se odigrava unutar intervala otpora, i to kada MOM 3 teži ka nuli (Model 5). Na ovakav način određene reperne vrijednosti impulsa predviđaju rast $L K$ i do godinu dana prije nego što do njega zaista dođe.

$R O C$ funkcioniše isto kao i MOM samo što on mjeri relativne, a ne apsolutne promjene. Unutar intervala otpora, ključne vrijednosti $R O C$ koje signaliziraju rast $L K$ su oko 0 , oko 20 , i ispod $40 \mathrm{za} R O C 3, R O C 6 \mathrm{i}$ ROC 10 respektivno (Model 4).

Primjenjeni alati tehničke analize nagovještavaju promjenu trenda mnogo ranije nego što do nje dolazi. Promjena trenda postaje očigledna na prelazu od Q3 2009 ka Q4 2009, kada $L K$ rastu sa 4,8 na 5,9 p.p. Alati tehničke analize anticipiraju ovu promjenu čak i do 2 godine ranije.

Predviđanje promjena $L K$ alatima tehničke analize bi moglo biti mnogo efikasnije da se raspolaže sa dužom vremenskom serijom, ili podacima veće frekvencije - npr. mjesečnim podacima. Naravno, idealno bi bilo da su podaci dnevni ili barem sedmični.

$D P$ se ponašaju kao dobra zamjena (proxy) za $L K .95 \%$ varijabiliteta $L K$ se objašnjava sa promjenom $D P$. Rast $D P$ za 1 p.p. povećava $L K$ za 1,5 p.p. $D P$ su, sa obzirom na visoku korelaciju sa $L K(0,98)$, a zbog manje diskrecije $\mathrm{u}$ njihovom bilansiranju, pouzdan indikator kvaliteta kredita (Model 7). Nedostatak modela sa vremenskim pomakom $L K=2,49+D P(-1)$, (Model 8) je nizak koeficjent determinacije od 0,67 i visoka $p$ vrijednost koeficijenta nagiba.

Već u 2004. g. opadajući trend DP slabi, promjena u odnosu na 2003. g. je - 0,6 p.p. U 
reach the local maximum. Stopping the growth of NPLs fits into the limits-to-growth concept and supports the principle that every phenomenon, after a period of intense growth, enters a stage of slower growth, end of growth, and decline.

In the banking systems characterized by a rapid decline of NPLs, preceded and/or followed by a credit expansion, a second-order polynomial is the best theoretical approximation of NPLs trends. The same goes for the second-order polynomial in the period of strong NPLs growth. Moreover, it is a useful tool for short-term prediction of NPLs. Adopting a rather rigorous and extremely optimistic assumption that the NPLS will follow the created polynomial model even in the medium term (Graph 12), in 2016 forecasts the NPLs in the interval between $5 \%$ and $3 \%$. It is in that interval that resistance should be formed to further decline of NPLs. After the decline in NPLs stops, the secondorder polynomial is no longer suitable for further prediction of the NPLS movements, unless history repeats itself in the absolutely exact form, which is either an impossible event, or a highly unlikely event, or an event repeated in the distant past. The optimism of this model comes as a consequence of its structure. Its independent variable is the time itself, i.e. the passage of time, and the fundamental banking or economic variables may be, but are typically not represented and featured. The polynomials are divided by the NPLs stagnation period, i.e. the time in which resistance to the further decline of NPLS is formed. Formation of the resistance level, a technical analysis tool, enables the division of the time series and the formation of the polynomials, which, each in its own section, excellently approximate the NPLS movements. The resistance level signifies the end of one trend and the beginning of another trend. The concept of technical analysis is, overall, intertwined with the time series analysis.

Graph 11. NPLs during a decline, (Q3 2003-Q3 2008), Model $14^{*}$

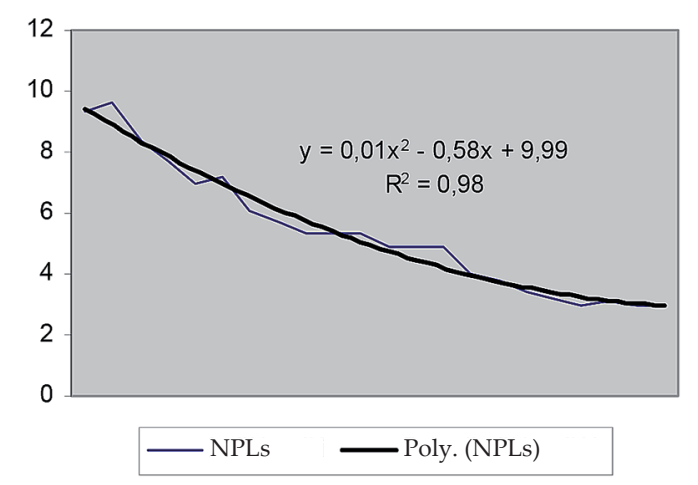

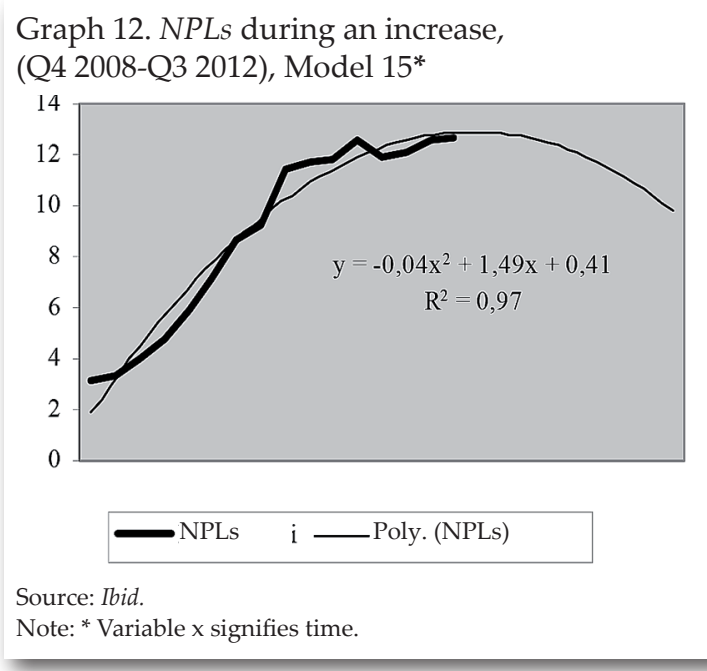

\section{Conclusion}

Using different methodologies, we have developed 15 models (Table 9) for predicting NPLs. The hypotheses of our research have been proven: 1) predicting NPLS requires a combination of various methodologies 2) different forecasting models are suitable for different periods of NPLS development 3) technical analysis is one of the methods/models for forecasting NPLs.

The NPLs time series is extremely variable. In the period 2000-2012, the minimal level of NPLS was $3 \%$. The maximum value of NPLs was $21.2 \%$ - the long tail is formed in the right section of the distribution. Probability that NPLs will take extremely low values, below 3\%, and extremely high values, above $12.1 \%$, amounts to $7.3 \%$ and $12.2 \%$ respectively (Model 1 ). The most frequent $(41.5 \%)$ values of NPLs are between $3.1 \%$ and $6 \%$. The arithmetic mean of the NPLs series is $7.59 \%$, and the median is $6.1 \%$.

Using the tools of technical analysis, trend lines and support/resistance levels, one can anticipate the the changes in NPLS trends. A trend line identified the possibility for a trend change already in Q4 2007 and Q3 2008 (Model 2). The support level, or, in line with the characteristics of the NPLS series, resistance level of 3\% was formed in Q2 2007 and lasted until Q1 2009. Based on the formed resistance level, already in the second half of 2007 it could have been known that there would be a change in the trend and growth of NPLs (Model 3).

Similar predictive ability is featured by momentum (MOM) and rate of change (ROC). MOM 10 suggests a change in the NPLs trend 
sljedeće tri godine (do 2007. g) godišnji pad DP je stalno ispod - 1 p.p., da bi u 2008. g. došao do - 0,1 p.p. Nakon toga, u 2009. g., DP rastu za 1,5 p.p. Indicija rasta $L K$ postoji već u u 2007. g. kada je pad $D P$ svega - 0,5 p.p. (Model 6) što je za oko dvije trećine manje od -1,3 p.p. za koliko je $D P$ smanjen u 2003. g. Usporenje pada $D P$ je očigledno već u 2004. g. ograničeni, period (Q1 2009 - Q2 2010) u kojem postoji inverzan odnos između varijabli. Model 11 je djelimično upotrebljiv za predviđanje $L K$, tj. upotrebljiv je za period tokom kojeg postoji, ili tokom kojeg se očekuje inverzija u kretanju $L K$ i $K R$. Standardna greška modela je 0,74.

Model 12 ima preveliku $p$ vrijednost ocjene koeficijenata modela. On se ne može upotrjebiti

Tabela 9. Pregled modela

\begin{tabular}{|c|c|c|c|c|c|c|}
\hline $\begin{array}{l}\text { R. B. } \\
\text { modela }\end{array}$ & Opis modela/metodologije & $R^{2}$ & $\begin{array}{l}p \text { vrijednost } \\
\text { koeficijenta } \\
\text { modela }\end{array}$ & Period & $\begin{array}{c}\text { Standardna } \\
\text { greška } \\
\text { modela }\end{array}$ & $\begin{array}{c}U \\
/ N / \\
D U^{*}\end{array}$ \\
\hline 1. & $\begin{array}{l}\text { Distribucija frekvencije i deskriptivna } \\
\text { statistika }\end{array}$ & - & - & Q4 2000 - Q3 2012 & & $\mathrm{U}$ \\
\hline 2. & Tehnička analiza - linija trenda & - & - & Q4 2000 - Q3 2012 & & $\mathrm{U}$ \\
\hline 3. & Tehnička analiza - nivo otpora/podrške & - & - & Q4 2000 - Q3 2012 & & $\mathrm{U}$ \\
\hline 4. & Tehnička analiza - $R O C /$ stopa promjene & - & - & Q4 2000 - Q3 2012 & & $\mathrm{U}$ \\
\hline 5. & Tehnička analiza - MOM/impuls & - & - & Q4 2000 - Q3 2012 & & $\mathrm{U}$ \\
\hline 6. & Godišnji prirast dospjelih potraživanja & - & - & $2000-2011$ & & $\mathrm{U}$ \\
\hline 7. & $L K=1,5528 D P$ & 0,95 & 0 & $2000-2011$ & 0,95 & U \\
\hline 8. & $L K=2,49+1,008 D P(-1)$ & 0,67 & 0,14 & $2001-2011$ & 2,79 & $N$ \\
\hline 9. & $L K=-0,788 B D P$ P.r. $+13,17$ & 0,935 & 0 & $2003-2011$ & 0,97 & U \\
\hline 10. & $L K=-0,52^{*} B D P_{\text {s.r. }}(-1)+10,23$ & 0,744 & 0 & $2004-2011$ & 1,9 & $D U$ \\
\hline 11. & $L K=3,51 K R-10,10$ & 0,9 & 0,018 & Q1 2009 - Q2 2010 & 0,74 & $D U$ \\
\hline 12. & $L K=0,692+0,797 K R$ & 0,83 & 0,149 & Q3 2004 - Q3 2008 & 0,54 & $N$ \\
\hline 13. & $L K=0,929+0,699 K R(-1)$ & 0,87 & 0,022 & Q4 2004 - Q3 2008 & 0,40 & $N$ \\
\hline 14. & $L K=0,01 x^{2}-0,58 x+9,99$ & 0,98 & 0 & Q3 2003 - Q3 2008 & 0,26 & $D U$ \\
\hline 15. & $L K=-0,04 x^{2}+1,49+0,41$ & 0,97 & 0,51 & Q4 2008 - Q3 2012 & 0,08 & DU \\
\hline
\end{tabular}

Izvor: Ibid.

Napomena:

*U - upotrebljiv, $N$ - neupotrebljiv, $D U$ - djelimično upotrebljiv.

Logika u pozadini svih primjenjenih prognostičkih alata promjene trenda $L K$ je pravilo, da kao što postoji granica rasta, isto tako mora postojati i granica pada. U BiH za $L K$ granica pada je 3\% (2007. g. i 2008. g.), a za DP 2\% (2007. g.). To pokazuje finansijska statistika $B S B i H$.

Veza između BDP s.r. i $L K$ je vrlo jaka (Model 9). $B D P$ s.r. objašnjava $93 \%$ varijabiliteta $L K$, a $p$ vrijednost koeficijenata modela je nula. Model 9 se približava idealnom modelu.

Ocjena koeficijenata modela sa vremenskim pomakom ( $L K=-0,52^{*} B D P$ s.r. $(-1)+10,23$, Model $10)$ je odlična ( $p$ vrijednost nula), ali je model ipak slabiji od prethodnog, jer je koeficijent determinacije manji i iznosi 0,744. Model 10 je djelimično upotrebljiv.

$L K$ smo stavili u odnos sa $K R$. Model 11 je inverzija modela $K S=f(L K)$. Njegov $R^{2}$ je visok $(0,9)$, a najviša $p$ vrijednost niska; 0,018. Linearna funkcionalna zavisnost između $L K$ i $K R$ je vrlo visoka i pouzdana, ali samo za jedan mali, za predviđanje $L K$. Njegova varijacija sa vremenskim pomakom, Model 13, ima visok $R^{2} \mathrm{i}$ nisku $p$ vrijednost 0,022 . Po svojim elementima/ specifikaciji, on se može iskoristiti samo za predviđanje nižih/niskih vrijednosti $L K$, jer za visoke vrijednosti $L K$ trebaju izuzetno visoke, praktično nemoguće, vrijednosti $K R$.

Sa daljom izgradnjom tržišno-orijentisanog modela bankarskog sistema, smanjenjem oligopolske i monopolske renete, očekujemo uspostavljanje veća i duže inverzne saglasnosti između $L K$ i $K R$.

Model 14i Model 15 su polinomi drugog reda. Prvi je izvanredna aproksimacija kretanja $L K$ tokom njegovog pada $\left(R^{2}=0,98\right)$, a drugi tokom rasta. Sa Modelom 15, pod pretpostavkom da u bilansima $B S B i H$ nema skrivenih gubitaka, i pod pretpostavkom da varijabla vrijeme sadrži u sebi osnovne ekonomske varijable, mogu se, sa velikim stepenom pouzdanosti $\left(R^{2}=0,97\right)$ predvidjeti vrijednosti $L K$. 
when the decline slowed down to values below 2 p.p., and MOM 6 to below 1 p.p. The announced shift takes place within the resistance interval, when MOM 3 approaches zero (Model 5). Thus, certain benchmark values of the momentum suggest a growth in NPLs up to one year before it actually occurs.

$R O C$ functions just like MOM except that it measures relative, instead of absolute changes. Within the resistance interval, the key values of ROC signaling a growth of NPLS are about 0 , about 20, and below 40 for ROC 3, ROC 6 and ROC 10 respectively (Model 4).

The applied tools of technical analysis suggest a change in the trend much earlier than it actually occurs. The trend change becomes obvious at the turn of Q3 2009 to Q4 2009, when NPLs grow from 4.8 to 5.9 p.p. Technical analysis tools anticipate this change up to 2 years earlier.

Anticipating the changes in NPLs trends by means of technical analysis could be much more efficient if longer time series were available, or data of higher frequency - for instance, monthly data. Of course, it would be ideal to have daily or at least weekly data.

MR behave as a good proxy for NPLS. $95 \%$ of the NPLs variability is explained by a change in $M R$. The growth of $M R$ by 1 p.p. increases NPLS by 1.5 p.p. $M R$ are, given the high correlation with NPLs (0.98), and due to the lower discretion in their balancing, a reliable indicator of loan quality (Model 7). A drawback of the model with a time lag $(N P L s=2.49+M R(-1))$, i.e. Model 8 , is the low determination coefficient at 0.67 and the high $p$ value of the skewness coefficient.

Already in 2004 the declining $M R$ trend weakens, and the change compared to 2003 is -0.6 p.p. In the next three years (until 2007) the annual decline of $M R$ was constantly below -1 p.p., only to reach -0.1 p.p. in 2008. After that, in $2009, M R$ increased by 1.5 p.p. The indication of NPLs growth was present already in 2007 when the decline of $M R$ amounted to only -0.5 p.p. (Model 6), which was by about two thirds less than -1.3 p.p., as had been the reduction of $M R$ back n 2003. Decelerated decline of $M R$ was evident already in 2004.

Table 9. Models Review

\begin{tabular}{|c|c|c|c|c|c|c|}
\hline Ord. no. & $\begin{array}{l}\text { Description of the model/ } \\
\text { methodology }\end{array}$ & $R^{2}$ & $\begin{array}{l}p \text { value of } \\
\text { the model's } \\
\text { coefficient }\end{array}$ & Period & $\begin{array}{l}\text { Standard } \\
\text { error of the } \\
\text { model }\end{array}$ & $\begin{array}{c}U \\
/ N / \\
D U^{*}\end{array}$ \\
\hline 1. & $\begin{array}{l}\text { Frequency distribution and descriptive } \\
\text { statistics }\end{array}$ & - & - & Q4 2000 - Q3 2012 & & $\mathrm{U}$ \\
\hline 2. & Technical analysis - trend line & - & - & Q4 2000 - Q3 2012 & & $\mathrm{U}$ \\
\hline 3. & $\begin{array}{l}\text { Technical analysis - resistance/support } \\
\text { level }\end{array}$ & - & - & Q4 2000 - Q3 2012 & & $\mathrm{U}$ \\
\hline 4. & Technical analysis - ROC & - & - & Q4 2000 - Q3 2012 & & $\mathrm{U}$ \\
\hline 5. & Technical analysis - MOM & - & - & Q4 2000 - Q3 2012 & & $\mathrm{U}$ \\
\hline 6. & $\begin{array}{l}\text { Annual growth/decline of matured } \\
\text { receivables }\end{array}$ & - & - & $2000-2011$ & & $\mathrm{U}$ \\
\hline 7. & $N P L s=1.5528 M R$ & 0.95 & 0 & $2000-2011$ & 0.95 & $U$ \\
\hline 8. & $N P L s=2.49+1.008 M R(-1)$ & 0.67 & 0.14 & $2001-2011$ & 2.79 & $N$ \\
\hline 9. & $N P L s=-0.788 G D P g . r .+13.17$ & 0.935 & 0 & $2003-2011$ & 0.97 & $U$ \\
\hline 10. & $N P L s=-0.52 * G D P g . r .(-1)+10.23$ & 0.744 & 0 & $2004-2011$ & 1.9 & $D U$ \\
\hline 11. & $N P L S=3.51 I R S-10.10$ & 0.9 & 0.018 & Q1 2009 - Q2 2010 & 0.74 & $D U$ \\
\hline 12. & NPLS $=0.692+0.797 I R S$ & 0.83 & 0.149 & Q3 2004 - Q3 2008 & 0.54 & $N$ \\
\hline 13. & $N P L s=0.929+0.699 \operatorname{IRS}(-1)$ & 0.87 & 0.022 & Q4 2004 - Q3 2008 & 0.40 & $N$ \\
\hline 14. & $N P L s=0.01 x^{2}-0.58 x+9.99$ & 0.98 & 0 & Q3 2003 - Q3 2008 & 0.26 & $D U$ \\
\hline 15. & NPLs $=-0.04 x^{2}+1.49+0.41$ & 0.97 & 0.51 & Q4 2008 - Q3 2012 & 0.08 & $\overline{D U}$ \\
\hline
\end{tabular}




\section{Literatura / References}

1. Božić, Radomir. 1999. Bankarske krize $i$ restrukturiranje banaka. Srpsko Sarajevo: Ekonomski fakultet.

2. Steven B. Achelis. 2001. Technical Analysis from $A$ to Z. New York: McGraw-Hill.

3. Žižić, et al. 1992. Metodi statističke analize. Beograd: Savremena administracija.

4. Socol, Adela i Iuga, Julia. 2010. Study of correlation between average interest rate and non-performing loans in the Romanian banking system during 2006-february 2010. Annals of the University of Oradea, Economic Science Series, Vol. 19 Issue 2: 777-782.

5. Evelyn, Richard. 2011. Factors That Cause Non-Performing Loans in Commercial Banks in Tanzania and Strategies to Resolve Them. Journal of Management Policy \& Practice, Vol. 12 Issue 7: 50-58.

6. Raef, Bahrini. 2011. Empirical analysis of non-performing loans in the case of Tunisian banks. Journal of Business Studies Quarterly, Vol. 3 Issue 1: 230-245.

7. Greenidge, Kevin i Grosvener, Tiffany. 2010. Forecasting Non-Performing loans in Barbados. Journal of Bussines \& Economics in Emerging Economies, Vol. 5 Issue 1: 79-108.

8. Louzis, Dimitros P. et al. 2012. Macroeconomic and bank-specific determinants of nonperforming loans in Greece: A comparative study of mortgage, business and consumer loan portfolios. Journal of Bussines \& Finance, Vol. 36 Issue 4: 1012-1027.

9. Siddiqui, Saad. 2012. Impact of Interest Rate Volatility on Non-Performing Loans in Pakistan. International Research Journal of Finance \& Economics, Vol. 36 Issue 84: 66-75.

10. Agencija za bankarstvo Republike Srpske. (2012). Izvještaji o stanju u bankarskom sektoru Republike Srpske 1999 - 2012. g. www.abrs.ba. (pristupljeno 19.07.2012. g.)

11. Agencija za bankarstvo Federacije Bosne i Hercegovine. 2012. Informacije o stanju u bankarskom sistemu Federacije Bosne i Hercegovine 1999 - 2012. g. www.fba.ba. (pristupljeno 19.07.2012. g.)

12. Centralna banka Bosne i Hercegovine. http:// www.cbbh.ba/index.php?id=618\&lang=bs (pristupljeno 10.10.2012. g.)
Uočene zakonitosti između kretanja vrijednosti posmatranih varijabli, posebno snaga veze, moraju proći kroz proces dodatne naučne verifikacije. Razvoj bankarskog poslovanja će ili potvrditi, ili demantovati, postavljene i u ovome istraživanju dokazane, hipoteze. Prezentovani rezultati su samo početak dubljeg i preciznijeg razumjevanja odnosa između ključnih varijabli u BSBiH i mogućnosti njihovog predviđanja.

Dalja istraživanja $L K$ se mogu kretati u smjeru izgradnje višestrukih linearnih i nelinearnih regresionih modela koji na još precizniji način objašnjavaju uzročno-posljedične veze između $L K$ i bankarskih/makroekonomskih varijabli. 
The logic behind all the applied diagnostic tools concerning NPLs trend changes is the rule that, just like there is a limit to growth, there must be a limit to decline. In $B \mathcal{E} H$ the limit to decline of NPLs is 3\% (2007 and 2008), and for MR 2\% (2007). This has been indicated by the financial statistics of $B S B \mathcal{E} H$.

The correlation between GDP g.r. and NPLs is very strong (Model 9). GDP g.r. explains $93 \%$ of the NPLs variability, and $p$ value of the model's coefficient equals zero. Model 9 approaches the ideal model.

The assessment of coefficients in the model with a time lag (NPLS $=-0.52^{*}$ GDPg.r. $(-1)+10.23$, Model 10) is excellent ( $p$ value equals zero), but the model is still weaker than the previous one, given that its determination coefficient is lower and amounts to 0.744 . Model 10 is partially usable.

NPLS were put in correlation with IRS. Model 11 is the inverse model $I R=f(N P L s)$. Its $R^{2}$ is high (0.9), and the highest $p$ value is low, i.e. 0.018 . The linear functional dependence between NPLs and IRS is very high and reliable, but only for a small, limited period (Q1 2009Q2 2010) during which there is an inverse correlation between the variables. Model 11 is partially usable for predicting NPLs, meaning that it is only usable during the period in which the trends between NPLS and IRS are, or are expected to be, inverse. The standard error of the model is 0.74 .

Model 12 has an excessively high $p$ value in the assessment of the model's coefficients. It cannot be used for forecasting NPLs. Its variation with a time lag, Model 13, has a high $R^{2}$ and a low $p$ value at 0.022 . Based on its elements/specification, it can only be used to forecast lower/low values of NPLs, because the high values of NPLs require extremely high, practically impossible, IRS values.

With a further development of the marketoriented model of the banking system, implying a reduced oligopoly and monopoly rent, we expect the establishment of a higher and longer inverse correlation between the NPLs and the IRS.

Model 14 and Model 15 are second-order polynomials. The first is an extraordinary approximation of the NPLs trends during their decline $\left(R^{2}=0.98\right)$, and the second during their growth. Under the assumption that there are no hidden losses in the balance sheets of the $B S B \mathcal{E} H$, and that the variable of time contains in itself the basic economic variables, Model 15 may predict the NPLs values with a high level of reliability $\left(R^{2}=0.97\right)$.

The detected rules concerning the trends in values of the observed variables, especially the correlation strength, must undergo the process of additional scientific verification. The development of banking business will either confirm or deny the hypotheses established and proven in this paper. Presented results are just the beginning of a deeper and more precise understanding of the relation among the key variables in the BSBEH and the possibility of their prediction.

Further research of NPLS can be directed at building multiple linear and non-linear regression models, describing even more precisely the cause and effect relations between NPLs and banking/macroeconomic variables. 